\title{
総説
}

[環境化学 (Joumal of Environmental Chemistry) Vol. 4, No. 1, pp. 1-18, 1994]

\section{地球環境における炭素循環と 海水中の溶存有機炭素の測定}

\author{
鈴木 款 \\ 静阊大学理学部地球科学科 \\ ( ॠ422 静岡市大谷836) \\ 伊藤 博 \\ (株)住化分析センター \\ （テ554 大阪市此花区春日出中3-1-135）
}

[平成 6 年 1 月 4 日受理]

\section{Globally Carbon Cycle and Measurement of Dissolved Organic Carbon in Sea Water}

\author{
Yoshimi SUZUKI \\ Institute of Geoscience, Faculty of Science, Shizuoka University \\ (836 Oya, Shizuoka 422) \\ Hiroshi ITO \\ Sumika Chemical Analysis Service \\ (3-1-135 Kasugade-Naka, Konohana-ku, Osaka 554)
}

[Received January, 4, 1994]

\begin{abstract}
Only about half of all the $\mathrm{CO}$, that has been produced by the burning of fossil fuels now remains in the atmosphere. The CO. missing from the atmosphere is the subject of an important debate. One of the great possibility of the missing $\mathrm{CO}$. is to know the pool and turn-over time of oceanic organic carbon, especially dissolved organic carbon in the carbon cycle. Measurement of dissolved organic carbon in seawater has been much argued for a long time. An essential discussion is described in relation to the understanding "Nature".
\end{abstract}

\section{1.はじめに}

19 世糺に,「ティンダル現象」で们多なイギリスの科

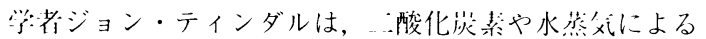
赫線の吸收を測足し、これらの父体の温效果に関す る先駆的な研究を行った。その後, スウェーデンの著多 な化学:者スバンテ・アレニウス, アメリカの地質受者卜

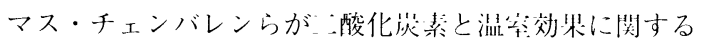

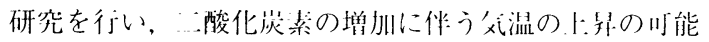
性について警俳をした。しかしながら、こ机らの研究に
もかかわらず，1950集代の終わりまで，酸化闵素と温主

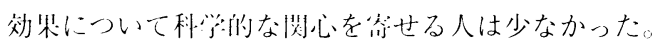

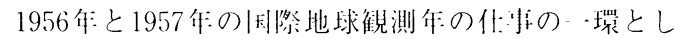
て，カリフォルニア人学スクリップス海洋研究所の チャールズ・キーリングが, ハワイのマウナロア川夏の 锶測所で一酸化荻素の測定を開始し，その測定は現在ま

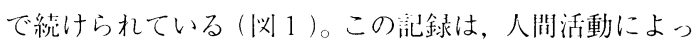
て、酸化荻素濃度が增加しているという明確な事実をホ し，我々に酸化桨素による“㴓効果”を思い起させ た。この䛉録はまた，父候滥嫒化という䦌題を通して人 


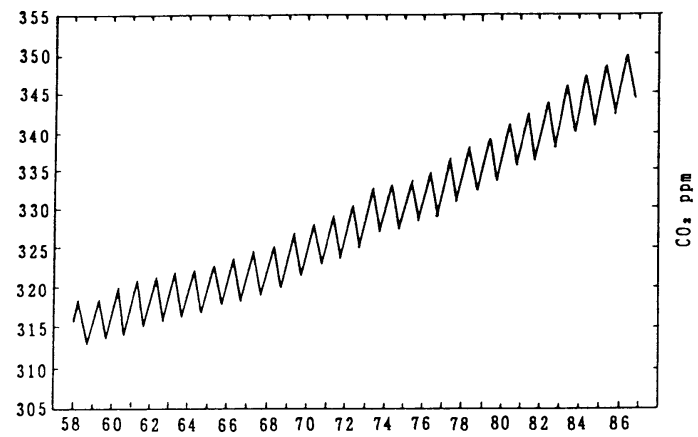

Figure 1 Concentration of carbon dioxide at Mauna Loa in Hawaii

(戌1 ハワイ島マウナロアの $\mathrm{CO}_{2}$ 濃度)

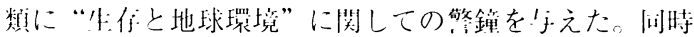
に目然の高みである牛颜と呼吸という「地球の牛们活動 の息」が酸化荻素を通して行わ机ていることをも我々

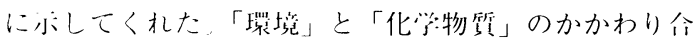
いをこれはよ゙ダイナミックに捉えている例は少ない。器

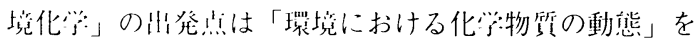
矨るということにあるここ机は、「球㑽の化学物啠」を どのように，どのくらいのレベルで「测定・分析」する かということを高味している，例えばマウナロアにおけ

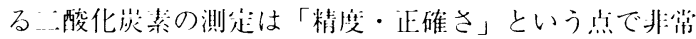
な然怔抁わ机ている。その結果として我々は「環境で 今，们が起こっているのか」を知り，そして何を考え， 似をなすべきかを判断できるようになる。ここでは環境

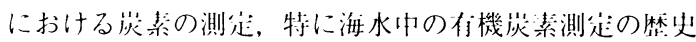
执よび現作の状沈を述べる。荻素分析のかかえている問 題を㖮じることは，単に份機菼幸分析法の現状を知るだ けでなく，培境，特に「地球罿境閏題」という視点での 測走・分析はどうあるべきかを理解するのに役市つであ ろう

\section{2. 炭素循環と測定の精度}

荻素は地球けの特分の你在には久かせない热であ る。そ机と间時に地球にのあらゆるところ，すなわち人 父淃，水淃，地淃，牛物淃に妄く分们している。また， 获絭はさまざまな化公物で仿作し，またさまざまな物

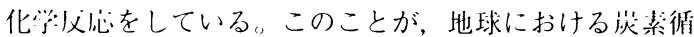
環を複雑なシステムとして機能させている理月である。 表 1 に地球上の主な荻素の期蔵庫とフラックスを亦し た。この表では，現仿量とフラックスが走常状態である

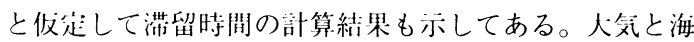
洋との岸素の分配比率は $1 ： 60$ であり，また陸上の生物 の現位里である560GT（GT は1099 Ton）に対する純基礎 生廉量は65GT，海洋牛物の現存荲である3GTに対する

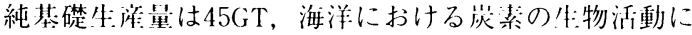
よる父換の速さは陸I:のそ机に比べて約160倸人きい。 さらに，二酸化炭素の大気・海洋間の父換により海洋は 78GTの交換量がある。これらのことから，海洋は‥酸 化炭素の溶解度に依存する交換と，生物生産に依存する 交換との双方で二酸化炭素濃度の調節を行っていると考 えられる。この自然のサイクルは，人間が介入して乱し 始めるまでは, 毎年周定される炭素量と生物の呼吸や分 解等のプロセスによって二酸化炭素の形で放出される炭 素量とはバランスがとれていた。海洋のプランクトンと 陸上の植物に着目すると，陸上:の植物は大気中から直接 に二酸化炭素を吸收利用しているが，海洋の植物プラン クトンは海水に溶解した二酸化炭素（炭酸水素イオン, 炭酸イオン, 溶存二酸化炭素) を利用している。すなわ ち，海洋生物および陸上生物は，大気中の炭素とそれぞ れ交換をしながら一つの独立。した炭素循環システムを構 築してきた。しかし近年，人間活動による化石燃料の燃 焼あるいは熱带林の減少により，大気中に‥酸化炭素か 放出され，大気中の二酸化炭素濃度が増加している。刚 2 に大気中の二酸化炭素濃度とRotty ら”の化石燃料か ら計算される積算放出量についての関係を小す。1958年 以降…酸化炭素の積算放出量の増加と其に大気中の二酸 化炭素濃度も増加している。毎年の積算放出量を対流淃 の空気の量で割算して大気残留率を計算すると, 放出さ れた二酸化炭素のおよそ $60 \%$ が大気中に残伱しているこ とがわかる。残りの40\%の行方を突き止めることができ ていない。これが “Missing Sink”「行方不明の吸収源」 として大きな関心を集めている問題であり，海洋への吸 収がもっと多いと考え研究しているグループと，文対に 森林などの生物淃がもっと多く吸収していると考え研究 しているグループとがある。

化れ燃料の消費による之酸化荻系の放出量は，1960年 代以降加速度的に增加し，1990年には約5.5GTに達し

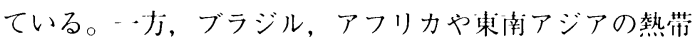
林等の燃覝によって，1980年代以降約1.6GTの .酸化 荻素が放出されて抢り，伞体で7.1GTの．酸化炭素か 大気中に放出されたことになる。60\%の残留摔を用いて “Missing Sink”の量を胡算すると2.84GTになる。こ の2.84GTの酸化荻紫が海洋に吸收されたのか，それ とも陸上の牛物惓で消費されているのかは現隹の研究段

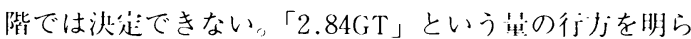

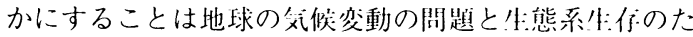
めにも重要である。この閆題解明のためには，1）地上 生物系は大父一酸化览素と平衡にあるのか，2）大気と 海洋の閶ではどうか，それぞれどの位の変動が自然幅に あるのかを知る必要がある。しかし，表1に亦されてい るように，自然の荻秦の譻蔵庫の量および循環の量は，

“Missing”している 酸化菼素の量に比べてはるかに 
Table 1 Main Carbon Pools and Flux

(表 1 地球の主な炭素プールとフラックス)

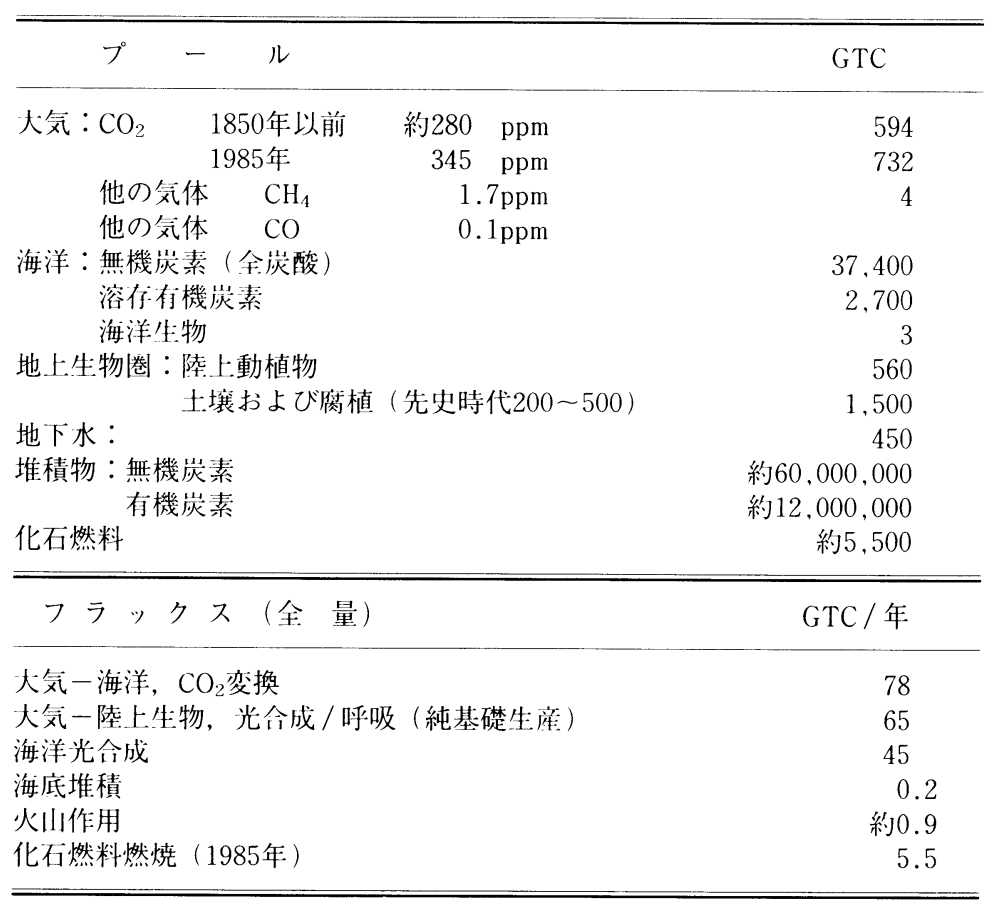

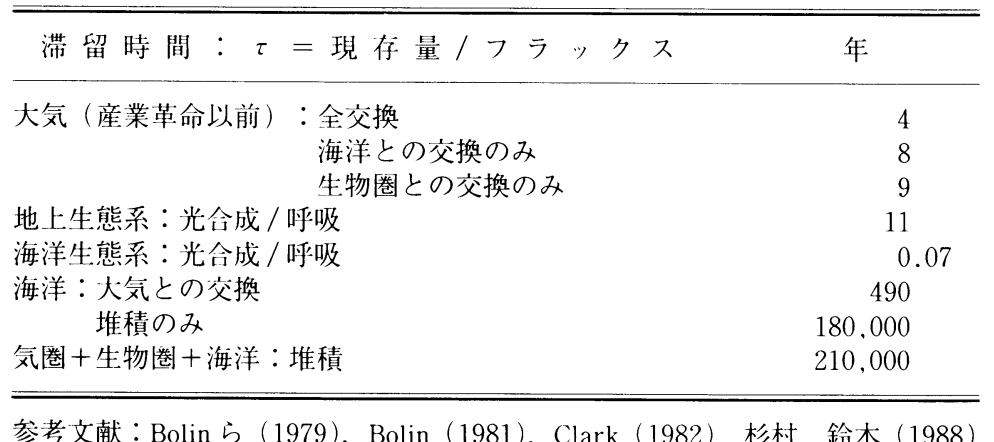

大きい量である。

表1の主然の荻素洎環の純フラックスの全量は189GT でありこ机に人為的起源のフラックスを加えると 196GTになる。このうち“Missing”している2.84GTは 約 $1.4 \%$ であるこの1.4\%という数字は，行方不明の荻

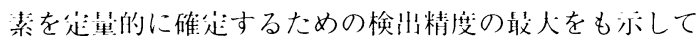
いる。こ机に然の変動幅を加えると，人為的に放出さ れた二酸化炭素がどこにどれくらい吸取されたかを算出 するためには $1 \%$ 以下の変動量を検出する必要がある。 大気・海水中の二酸化炭素の測定および海水中の全炭酸 の測定においては,この精度は達成さ机ている。しかし， 炎素循環のバランスを理解するためには, 無機苂素の測 走だけでは不十分であり，有機炭素の測定が久かせない。
この有機炭素の測定は, 土塞試料, 生物試料, 陸水試料, 海水試料などさまざまな試料について行われている。こ のうち, 土畩・生物等の同体試料については, すでに古 くから有機元素分析装置等が開発され，分析が行われて いる。ところが, 液体試料, 特に海水試料中の有機炭素

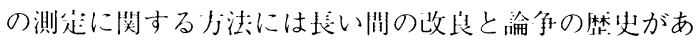
り，現在でもな扩確足していない。

\section{3. 海洋の炭素循環と溶存有機炭素}

大気と海洋間では一酸化炭素の交換が常時行わ机てい る。1960年代半ばより大気・海洋闒の二酸化炭素の分压

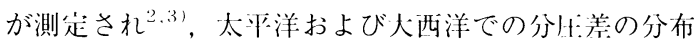
刚を得ることができるようになった。その結果に風速に 


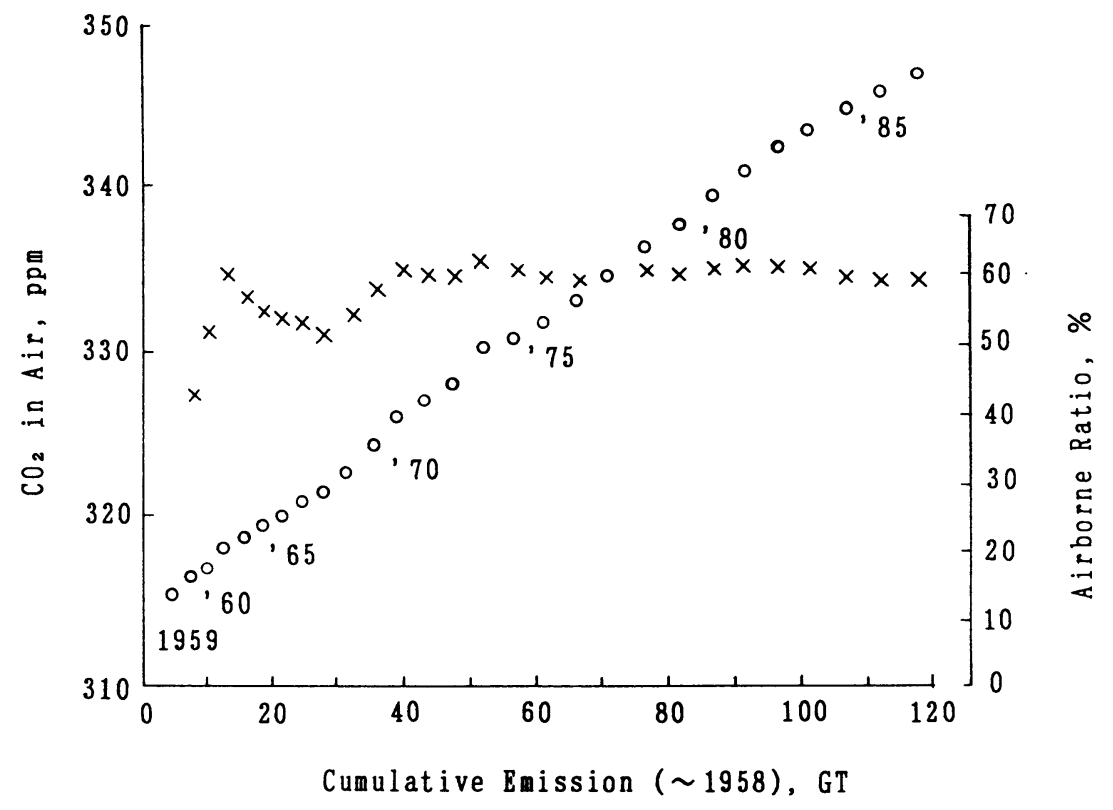

Figure 2 Relationship between cumulative emission of carbon dioxide, average concentration of atmospheric carbon dioxide and airborne ratio of carbon dioxide

(図 $2 \mathrm{CO}_{2}-\mathrm{C}$ 積算放出量と $\mathrm{CO}_{2}$ 平均濃度および大気残留率の関係)

$\bigcirc$; Concentration of carbon dioxide, $X$; airborne ratio of carbon dioxide.

よる交換係数の変化を加えて計算すると, 太平洋では南 北中緯度では吸収域となり, 赤道域および南太平洋東部 では放出域となっている。太平洋全体としては, 放出量 $2 \mathrm{GT} /$ 年, 吸収量 $1 \mathrm{GT} /$ 年であり, 放出域となっている。 一方, 大西洋は全体として, 吸収域であるため, 地球全 体ではほぼバランスしているようにみえる。しかし，こ の交換量の計算に用いられた父換倸数は、海域抢よび季 節で変動することが予測される。そのため, 表 1 に示し た大気・海洋間の年間交換量である78GTの1〜3\%に 当る吸収あるいは放出のバランスを決定するのは容易な ことではない。

大気・海洋の二酸化炭素の交換の問題は, 海洋表層水 の二酸化炭素分压を支配している因子の解明に関係して いる。これを支配しているものは, 海洋内部の炭素循環 である。网 3 に海洋の炭素循環を示す。海洋の炭素循環 の特徵をまとめると, 1) 無機炭素化合物（炭酸水素1 オン, 炭酸イオンあるいは溶存二酸化炭素) は海洋の植 物プランクトンの基礎生産のために利用され, 有機物 (精 子態お上び溶存態有機炭素) が生産される。2)生産さ れた有機炭素化合物のうち $80 \%$ 以上は有光層（水深0 $200 \mathrm{~m}$ ）と呼ばれる表層で分解され, 無機岑素化命物に もどる。10２0\%の有機炭素のうち, 粒子態 (数 $\mu \mathrm{m}$ 以 上のサイズ)の有機炭素は中梁層に沈降し, そこで分解
され無機炭素化合物にもどる。また，溶仔態の有機炭素 は海水の鉛直混令により中樑層に連ばれ, 分解し無機炭 素化合物にもどる。 3 ) 無機炭素化命物は, 岸酸カルシ ウムとして生物の殸 (ココリス, 有孔虫等) を作る。生 物が死滅すると, その遺骸は炭酸カルシウムとして中深 層に沈降し，その大部分は深層に打いて溶解する。その ため, 海洋においては, 無機の炭素化令物の濃度は表曾 で低く, 中深層で高い。文対に, 有機炭素化令物濃度は, 表層で高く，中深層で低い分布を示している。

“行方不明の二酸化炭素”を海洋に吸収させようとす ると，1）水温の低下に伴う二酸化炭素の溶解度の増大， 2 ) 生物生産の増大による二酸化炭素の䏽定の堌加が考 えられる。1)については“溶解度ポンプ”といわれ， 多くの研究がなされている。前述したように、この開題 は大気・海洋間の父換望の正確な決定に依你している。 2)については, “生物学的ポンプ”といわれ，能近人 気中の二酸化炭素の吸収との関係で非常に注目されてい る。海洋の年間の基礎生应量45GT が倠に4 5\%(2 3GT) 増加し, この行方不明の大気中の二酸化竾素星が 海洋で有機物として周定貯蔵され，しかもそれに相当す る量の有機炭素が中深層に輸送されるとすると説明でき る叮能性がある。

そこで問題は, 海洋の有機物, 特に海水中の们機荻素 


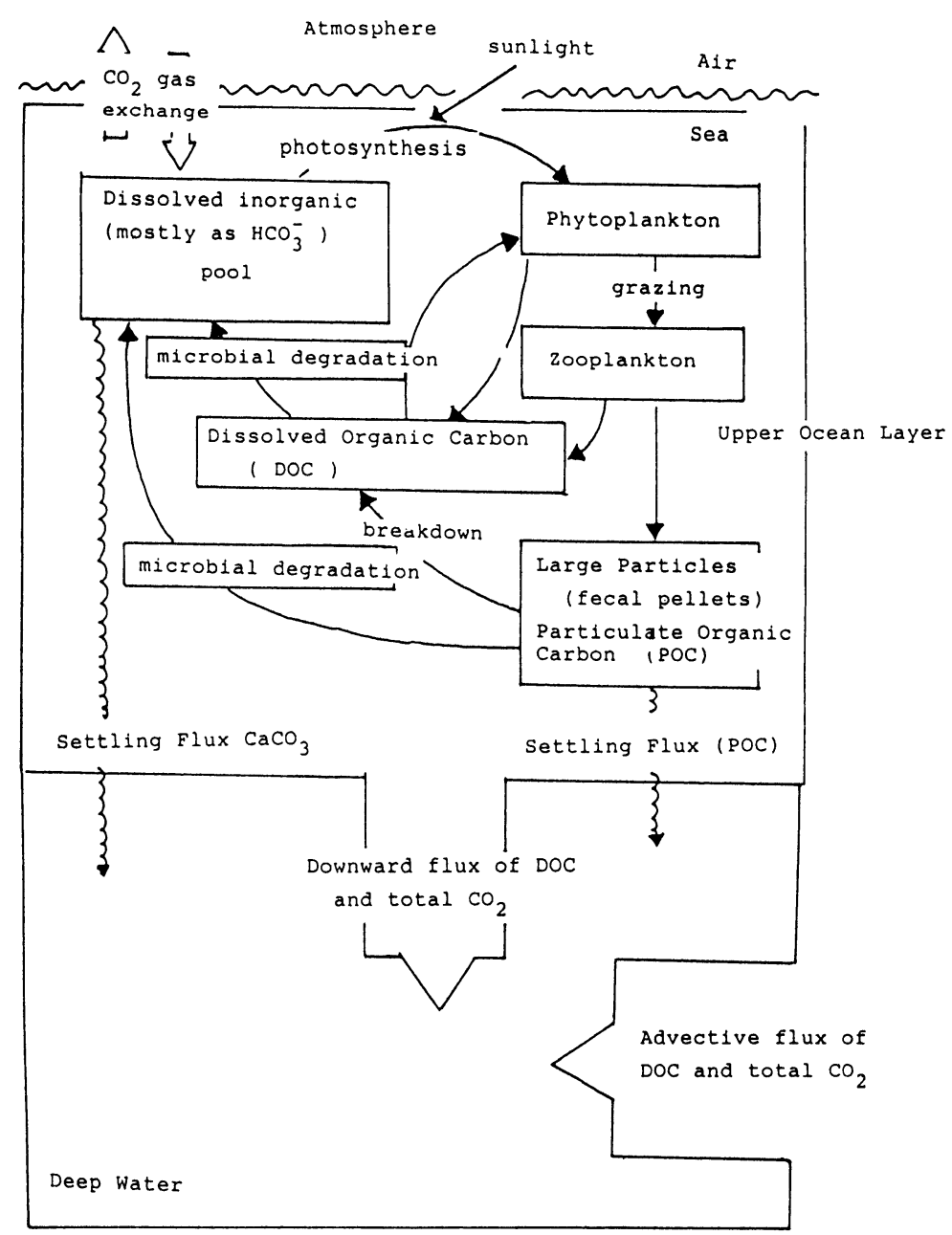

Figure 3 Carbon cycle in ocean

(Surface layer, 0-100 meter; deep layer, 100-4000 meter)

(戍 3 海洋における炭素循環（表層：0-100m，深層：100-4000m))

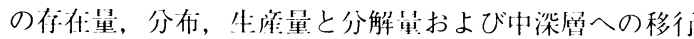
量がどのくらいかを明らかにすることである。海水中の 有機炭素は，存在状態により䊑子態と溶你態に区別され

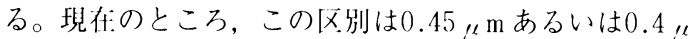
$\mathrm{m}$ の孔径をもつミリポアフィルターあるいは二ュウクレ アポアフィルターあるいは GFF，（GFCのようなガラス フィルターでろ過したときにフィルタートに捕捉される 部分を「粘子態」，通過する部分を「溶你態」と起義し ている。従って溶㐿態の部分は，物理化学で走義される “真”の溶仔とは買なり，微小档子拉よびコロイドを合 んでいる(佛 4$)$ 。

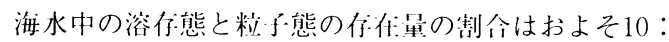
1 であり，海水中の垡機物の大部分が溶你態である。海
水中の有機物を構成している化令物として主なものは汹 4 に小されているように荻水化物, 蛋白質(ペプタイド, アミノ酸を含む)，脂肪酸，荻化水素挹よび鹪食酸である。 これらの化令物の濃度は做々に測定されている。しかし， こ机らの做々の住機化分物の濃度を炭素の濃度に換算 し，存機荻素として測定された䝑と比較すると，全有機 荻素量の 20 ～30\%が併明されるに過ぎない。残りはどの ように説明するのか。70 80\%が朴知の化令物であるの か, それとも湖々の标機化命物の分解測定に問題がある のか。このいつの例として最近, Keil と Kirchmann ${ }^{4)}$ 海水中のアミノ酸の測定にに执いて結介アミノ酸の分解法 として Vapor-Phase 加水分解法と彷来の塭酸加水分解法 を比較した。その結果, Vapor-Phase 法は従来法に比べ 


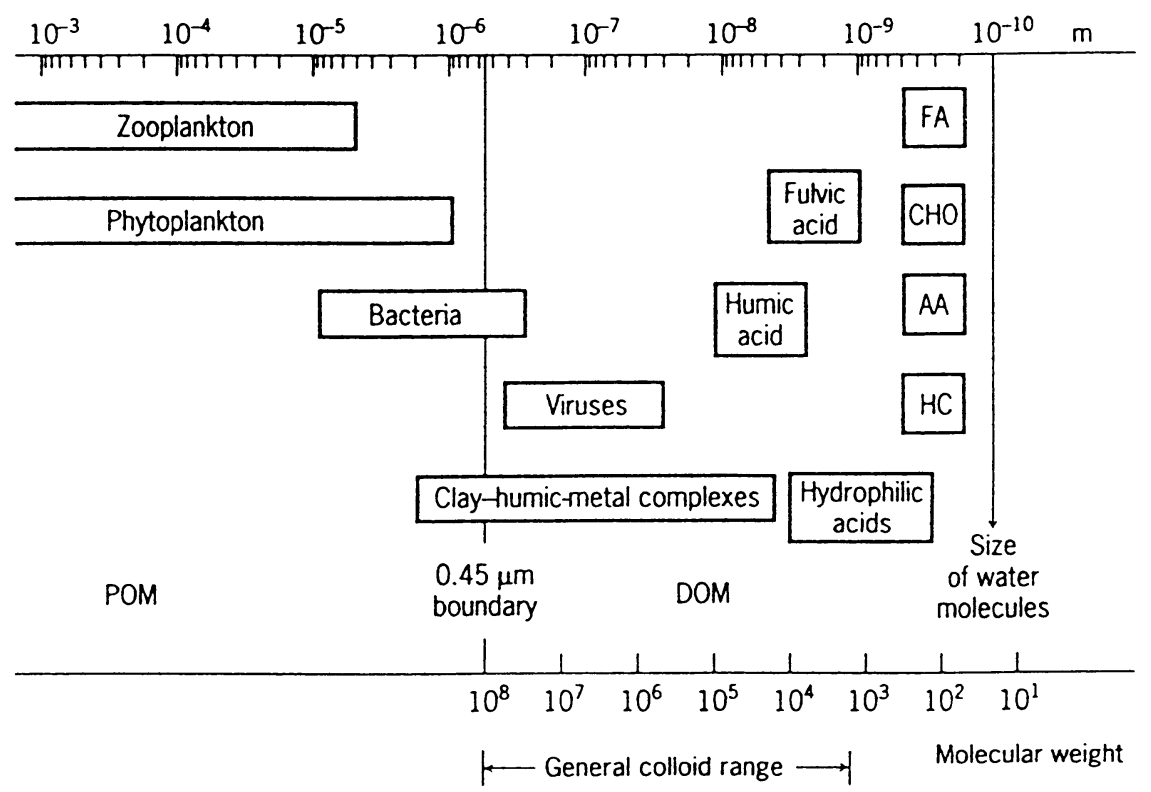

FA Fatty acids $\mathrm{CHO}$ Carbohydrates $\mathrm{AA}$ Amino acids $\mathrm{HC}$ Hydrocarbons

Figure 4 Definition and classification of particulate organic carbon and dissolved organic carbon in seawater

(図 4 海水中の粒子状および溶存有機炭素の定義と分類)

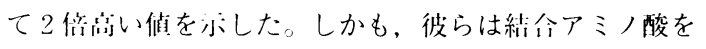

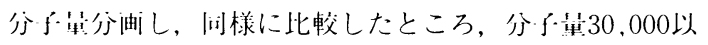
トの高分子分曲部分ほど善が大きいことを見出した。末 间走主の们機化公物の制令が70～80\%あるという問題は海 洋の们機地球化労:の “Enigma” (謎) で, 分解の方法に より筫なる做が得られることは，海水中の溶存何機物の 態解明と其に分析法の確立がいかに重要であるかを示 している。こ机に対して粒子態有機物の寒態解明はかな り進んで拈り，70８0\%が问定されているう。

現在まで海水中の浴你有機览素の起源として, 大部分 は海洋の植物プランクトンあるいは動物プランクトンあ るいはバクテリア篮の遺骸や代謝産物であると説明され ている。海洋の他，例えば河川あるいは大父から供給さ れる制公はおよそ10\%以下である。この生䊞された溶你

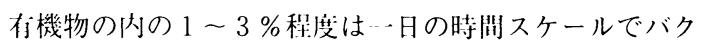
テリア等により分解消費される。さらに，70～80\%は 年から数年以内に分解消費されると考えられる ${ }^{61}$ 。残り の数\% 数十\%が海水中に数百年から数千年の時間ス ケールで滞留している。では, 現在まで海水中の溶存有 機物はどんな“性啠”をもっていると考えられてきたの か。海水中の DOC 濃度は, 空䦌的にも季節的にも変動
幅は小さく，しかもその年齢を放射性荻素を用いて測㳬 すると，およそ1000年から6000年という非常に古いもの であると報焋されてきた。この結果から，“浴你有機物” は生物の循環システムの中で役立つものはほとんど利用 され尽くした，もはやこれ以上分解されにくい“残渣” ではないかと考えられてきた。このことが，海洋の炭素 循環の生物的ダイナミックシステムの系から浴你有機炭 素の循環および役制を除外して考えるようになった大き な理由である。その結果，粒子態有機物の役割が海洋の 岑素循袈において支配的であるとして粘子態，特に沈降 粒子について多くの研究がおこなわれている゙!。ところ

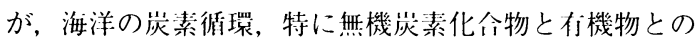
䦚のバランスを沈降粒子チだけで説明しようとすると，深 曾の無機燹秦化父物の増加, 酸素の消費量, 硝酸塩, リ ン酸塩の分布等の説明を走量的にすることができないこ とがわかってきた。さらに，生産された仿機物の80－90\% が表層で分解消費され，二酸化炭素に変るとすると，大 気の二酸化岸素は险衡として600ppmになることが予 測された。しかし，現篹にはそのようになっていないの で二酸化炭素には変わらず，有機炭素として保存されて いる叮能性がある。このような点から, 再び溶你有機炭 
素の䉓，分们，分解時䦌等を明らかにすることの重要性 が润目されだ。

そこで溶们们機悠素の䒠態がよくわかっていないこと を考虑すると，分析測分值拉よび方法が爱当であるのか どうか，もう・度検湖し淌すべく原点に帰る必要が牛じ てきた。しかも，一つの“パラドックス”は，生物学的 に分解しにくいものがなぜ化学的に酸化が寒易なのかと いう閏題である。

\section{4．海水中の溶存有機炭素測定の歴史と問 題点}

炭素の分析法は，遠く前世紀にLiebigによって考案 され，その後種々の改良が加えられたが，原理的には試 料中の炭素を二酸化炭素に変えて測定するという方法は 共通している。炭素分析法の全般についての解説あるい

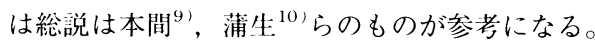

海水中の溶存態掞よび粒子態の表層から深層までの鉛 㨁分布においては, 海水表層の溶存有機炭素濃度は50 $200 \mu \mathrm{mol} / \mathrm{L}$ で深さと共に減少し, 深層ではその濃度は 30 $80 \mu \mathrm{mol} / \mathrm{L}$ を示す。また, 粒子態濃度は溶存態の 約 $1 / 10$ である。

海水中の溶存有機炭素（DOC）の分析に関する現代の 研究は, 1950年のSkopintsevに始まる。Skopintsev は乾 燥乾式燃焼法によりDOCの測定を行った。採水後, 海 水の一部をとり，水酸化カルシウムを分解し， 50 〜 $60^{\circ} \mathrm{C}$ で海水を乾固する。その試料を $850^{\circ} \mathrm{C}$ の電気炉で分解し, 生成する二酸化炭素を水酸化バリウムに吸収させ，滴定 法により測定した。この方法および改良法により1950年 代から1970年代にかけて Skopintsev, Timofeeva, Starikova や Romankevichの旧ソビエトの研究グループ は海水中の溶存有機炭素の濃度を測定し, $88 \sim 225 \mu$ $\mathrm{mol} / \mathrm{L}$ ，平均として $130 \mu \mathrm{mol} / \mathrm{L}$ の值を得た。これに対 して Duursma ${ }^{11)}$ は，海水を硫酸酸性で保存し（50mLの 海水に0.5mLの濃硫酸を加える)， クロム酸銀とカリウ 厶塩を加え， $130^{\circ} \mathrm{Cで}$ 加熱分解した後，生成した二酸化 炭素を水酸化バリウムに吸収させ，クーロメトリー滴定 法で定量した。彼は，この方法を用いて Shopintsevと 同じ海域でDOCを測定したが，その濃度は16〜100 $\mathrm{mol} / \mathrm{L}$ ，平均で $65 \mu \mathrm{mol} / \mathrm{L}$ とおよそ半分の值であった。 その後, Holm-Hansen ${ }^{121}$, Menzel \& Vaccaro ${ }^{131}$ らも海水

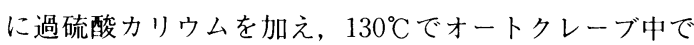
30分間加熱分解し, 生成した二酸化炭素を赤外線ガス分 析計で測定した。彼らの結果もまたDuursma と同じく Skopintsevらに比べて低い值であった。この差異はどこ から生じるのか。1）試料採取の際の容器および保存の 条件の違い，2）万過操作の違い，3）乾式法と化学的 分解法 (湿式法) の分解効率の差，4) 乾式法と湿式法 のブランク值の違い（乾式法は炭素のコンタミネーショ
ンが人り易いという考え）等が考えられる。例えば, Duursma ${ }^{14}$ によれば，採水した海水を乾燥していくうち に们機物は沈殿していくこと，また酸性により高分子有 機物は凝集し，溶仔有機物が減少することが明らかにさ れている。

汹 5 に1980年以前に異なる分解法で得られた北大西洋 の海水中の DOC 濃度の鉛脯分布を示してある。汹に示 されているように，乾式法による測定結果は湿式法より 高いことがわかる。同一の試料についてこのように測定 值が買なる問題を解決しなければ海洋の炭素循環あるい は有機地球化学:の研究を進めることはできない。そこで,

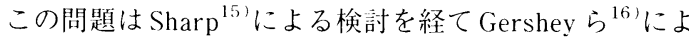
り組織的に検討された。特に闹…試料を用いて分解法 の違いについて比較検討された（汹 6 )。表 2 に比較検 討のために用いられた方法がまとめられている。方法と

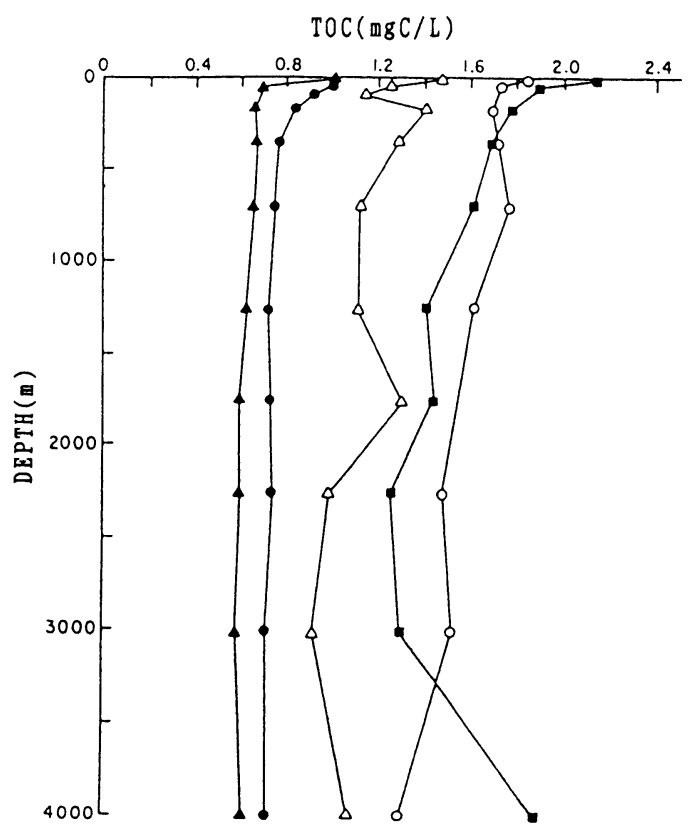

Figure 5 Indirect comparison of depth-averaged TOC concentrations measured in the northwestern Atlantic with different oxidation methods (MacKinnon, 1978).

(図 5 異なる酸化分解法による北西大西洋海水中 の TOC 濃度の鉛直分布)

- Menzel (1970), persulfate oxidation; Mackinnon (1978), dry oxidation; $\triangle$, Sharp (1973), direct injection; $\bigcirc$. Skopintsev et al. (1966), dry oxidation; $\square$, Gordon and Sutcliffe (1973), dry oxidation. 


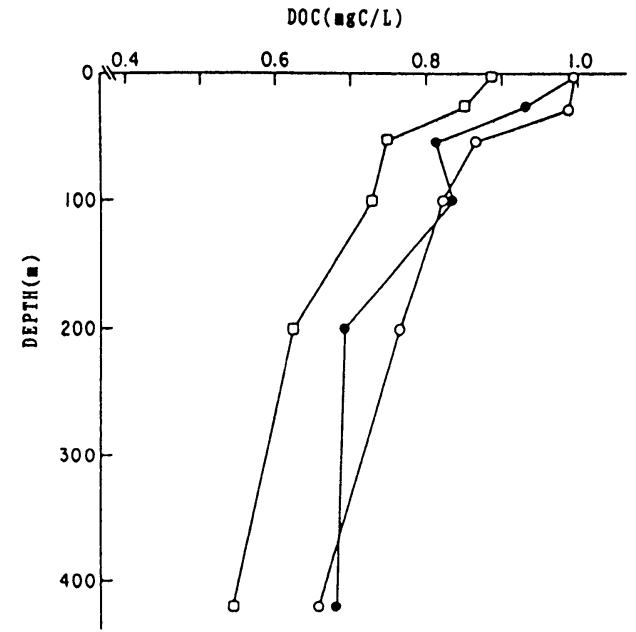

Figure 6 Comparison of depth-averaged profiles of dissolved organic carbon (DOC) concentrations of samples from the Nova Scotian shelf measured with various oxidation methods. Data from Gershey et al. (1979).

(図6 異なる酸化分解法によるNova Scotian 海 水中の DOC 濃度の鉛直分布の比較)

$\square=$ Persulfate oxidation (Menzel and Vaccaro, 1964); $\bigcirc=$ dry oxidation (MacKinnon, 1978) ; $\mathbf{O}=$ photo ozidation (Collins and Williams, 1977)
しては, 過硫酸カリウム酸化法, 紫外線照射分解法, 高 温燃焼酸化法が用いられた。Gershey らによれば高温燃 焼酸化法による測定值を $100 \%$ とすると, 紫外線照射法 では95\%, 過硫酸カリウム法では85～90\% と酸化効率が 僅かに低い結果が得られた。この結果から, 有機物の分 解法として三つの異なる方法の間には大きな差はないと した。またこの結果から, Skopintsevらにより得られた 高い值は分析の過程でのコンタミネーションによるもの であると考えられるようになった。この組織的な検討の 後，高温燃焼酸化法によるDOCの測定は，湿式法によ る測定と較べるとあまり簡便でないこと, デー夕の変動 が大きいこと，炭素により污染されやすいことなどから 敬遠されがちになった。

1980年代後半になると, 前に述べたように地球温暖化 問題に関係して二酸化炭素の海洋への吸収の可能性が再 び活発に議論されるようになった。特に, 生物による生 産と分解の過程が二酸化炭素の吸収にどのように関係し ているのか, さらに地球規模の炭素循環のモデルを構築 する上での溶存態および粒子態の有機物の役割とその海 洋のプールの大きさが非常に重要視されて, 新たな視点 から海洋の炭素循環を見直す動きが出てきた ${ }^{17.18) 。 こ ~}$ のような背景の中で鈴木らは, 図 5 に示された異なる力 法によるDOC 濃度の差は酸化効率の違いによるのでは ないかと考え, 従来の高温酸化燃焼法の問題点と改良す べき点を検討した。海水試料を高温分解する場合, 最大

Table 2 Comparison of oxidation methods used for analysis of organic matter in sea water

（表 2 海水中の有機炭素測定のために用いられた酸化分解法の比較）

\begin{tabular}{|c|c|c|c|}
\hline & $\begin{array}{l}\text { Persulfate oxidation } \\
\text { (Menzel and Vaccaro, 1964) }\end{array}$ & $\begin{array}{l}\text { Photo-oxidation } \\
\text { (Collins and Williams, 1977) }\end{array}$ & $\begin{array}{l}\text { Dry oxidation } \\
\text { (MacKinnon, 1978) }\end{array}$ \\
\hline 1. Completeness of oxidation & $\begin{array}{l}\text { incomplete }(85-90 \% \text { of dry } \\
\text { oxidation results })\end{array}$ & $\begin{array}{l}\text { complete }(>95 \% \text { of dry ox- } \\
\text { idation results })\end{array}$ & complete \\
\hline 2. Precision & variable & high & high \\
\hline 3. Blanks & $\begin{array}{l}\text { high and difficult to assess } \\
\text { accurately }\end{array}$ & low & low with proper precautions \\
\hline 4. Contamination & variable & low & low with proper precautions \\
\hline 5. Sample preparation & extensivw & minimal & minimal \\
\hline 6. Automation of analysis & possible & yes & not likely \\
\hline 7. Real-time analysis & possible & almost & no \\
\hline 8. Ship-board operation & yes & yes & not likely \\
\hline $\begin{array}{l}\text { 9. Changes with time in } \\
\text { accuracy of oxidation } \\
\text { system }\end{array}$ & no & $\begin{array}{l}\text { possible-must monitor } \\
\text { efficiency of UV lamp; simple } \\
\text { organic standards not } \\
\text { sufficient }\end{array}$ & no \\
\hline $\begin{array}{l}\text { 10. Problem with particles in } \\
\text { sample }\end{array}$ & no & yes & no \\
\hline 11. Loss of volatile organics & partial & partial & complete \\
\hline 12. Relative cost of equipment & low & high & low \\
\hline
\end{tabular}

This table has been made based on the results of comparison by Gershey et al. (1979). 
の問題は海塩の溶融である。すなわち筆者らは，海塩の 代表である食塩の溶融温度は約 $750^{\circ} \mathrm{C}$ であるのに対して， 従来の高温燃焼法において用いられた分解温度は $800^{\circ} \mathrm{C}$ 以上であるため海塭が溶融し, 酸化剂として用いられた 白金綿あるいは酸化銅を被覆して酸化能力を低下させ, かつ反応管に使用している石英管を損傷すると考えた。 そこで分解温度を $700^{\circ} \mathrm{C}$ 以下とし，その代り，高効泋の 酸化触媒（例えば白金担持触媒）を允填し, 酸化効摔を 高めることを考えた。その結果, 高温接触酸化法という 新しい溶存有機炭素の分析測定法が報告された8.191。そ の結果はSkopintsevらの結果を持現し，湿式法による 值に比べて50〜150\%高い僧を示した。この方法が報年 されて以来この高い值の信頼性について追試等が行われ た。現在,この高温接触酸化法は滈温然焼法の主流となっ ている。しかしながら，まだお法としては完成さ机て抢 らず，湿式法との比較においてさまざまな解沈すべき問 題が残されている。

\section{5. 海水中の溶存有機炭素測定の現状}

\section{1 分解法}

海水中の溶伱有機炭素の分解法は，4つのカテゴリー に分けられる。すなわち 1) 化学的酸化法，2）紫外線 照射法，3）高温燃焼法，4）高温接触酸化法である。

1 ) 化兴的酸化法

この方法はDOCの測定に敂も一般的で主く用いられ ているす法である。試料採取後、武水を酸性にし，光酸盐 を究素ガスで除去し，酸化剂を添加して酸化分解する。 このう法に扮ける酸化剂には，当初さまざまなものが朋

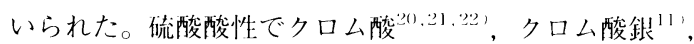

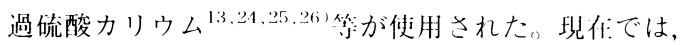
$\operatorname{Sharp}^{15)}$ により改高さ机た過硫酸カリウムによる分解法 が主流になっている。

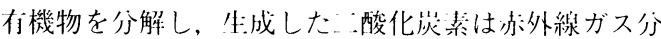

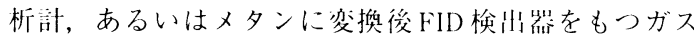
クロマトグラフィーにより測足される。このお法による 酸化摔はさまざまな不機化今物を用いて検湖され，ほと んどの存機化令物は95－100\%の回收㳯が得られて抢り， 既知の存機化仝物の分解測走に閶しては䦥題がないこと をホしている。しかし，㓩述したように，海水中の存機 化令物の70\%が间定さ机ていないことを考えたとき，と

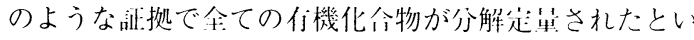
えるのか悓价のところその確琹のう法はない。この䦌題 は化学的酸化法に限らず，すべての分解法にいえること でありここに海水中の浴份们機菼素の分析の難しさと 新たな視点が荌求されるところである。またここれは溶

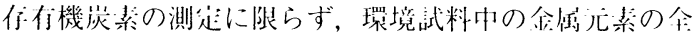

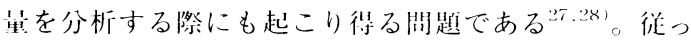
て，異なる分解法の絬果を相台に比較検部する以外にな
い。このような点から化学的酸化法の問題点を考えると Gersheyらによってまとめられた表 2 で明らかなよう に，高温酸化法に比べて低い值を示していることは，化 学的酸化法では分解できない有機化令物が海水中に存在 する川能性を示唆している。

2 ) 紫外線照射分解法

この方法も化学的分解法と间様に早くから用いられて きた 29331 。その後この诗は，リアルタイムで結果を 出せるように改良され，現在ではその改发法が用いられ

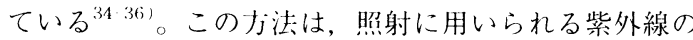
強度，紫外線ランプの㸃用のイ英キャピラリーの重さ， 照射時間, 化学的酸化剂の存無により海水中の溶存存機 物の分解効摔が買なる。分解後の測定はほとんどの場令, 赤外線ガス分析計によって行わ机ている。この才法の利 点は，酸化剂を武料に加えないために，こ机らのものか らの菼絜の活染についてほとんど考虑する必要がなく， ブランク値が低いとされている。閣題は, 化学的酸化法 の場令と间じく酸化効摔の点である。特に紫外線照射で 分解し易い侍機物は芳香族環をもっているものあるいは 其役‥重紏公をもっているものである。Gershey らゃ Collins とWilliamsらの結果では過硫酸カリウムを用い る化学:的酸化法と紫外線照射分解法による海水中の DOCの測定值にはほとんど善がないことが報苦されて いる。このうつのお法は，後に述べる乹式法に比べて武 料の荲を多く用いることができるなどの利点がある。こ のことは，分析の過程に扮いて試料に対する荻素の污染 の影薌を乾式法に比べて小さくすることになる。最近で は化器的酸化法と紫外線照射分解法を組及们せたす法 が用いら机ている（炍７にその・例をぶす）。

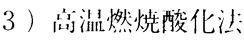

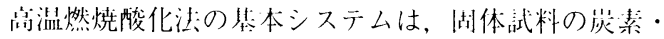

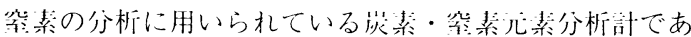
る。このシステムは，酸化剩あるいは主昘のアスベスト

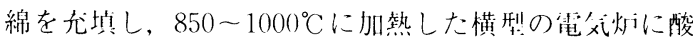
性で乾湖した武料を们英のボートで插人して酸化分解

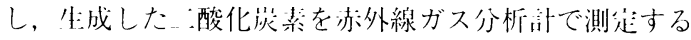
ものである。このお法の一例を㕳8に亦す。このお法の

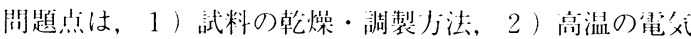
㶧内抢よび付近で用いられているパッキング、コネク

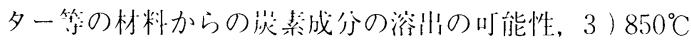
の高溫による海㙁の溶融とそれに伴う酸化剂の酸化能力 の低下の叮能性，およびィ英管の損傷，4）高温下にお

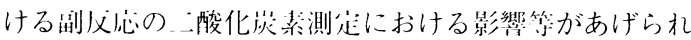
る。武料の乾燥の什少はフリーズドライ法河あるいは

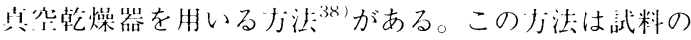

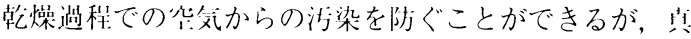
空ポンプのオイルからの菼化水素による活染のあること

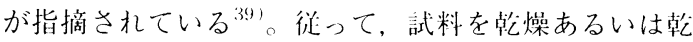




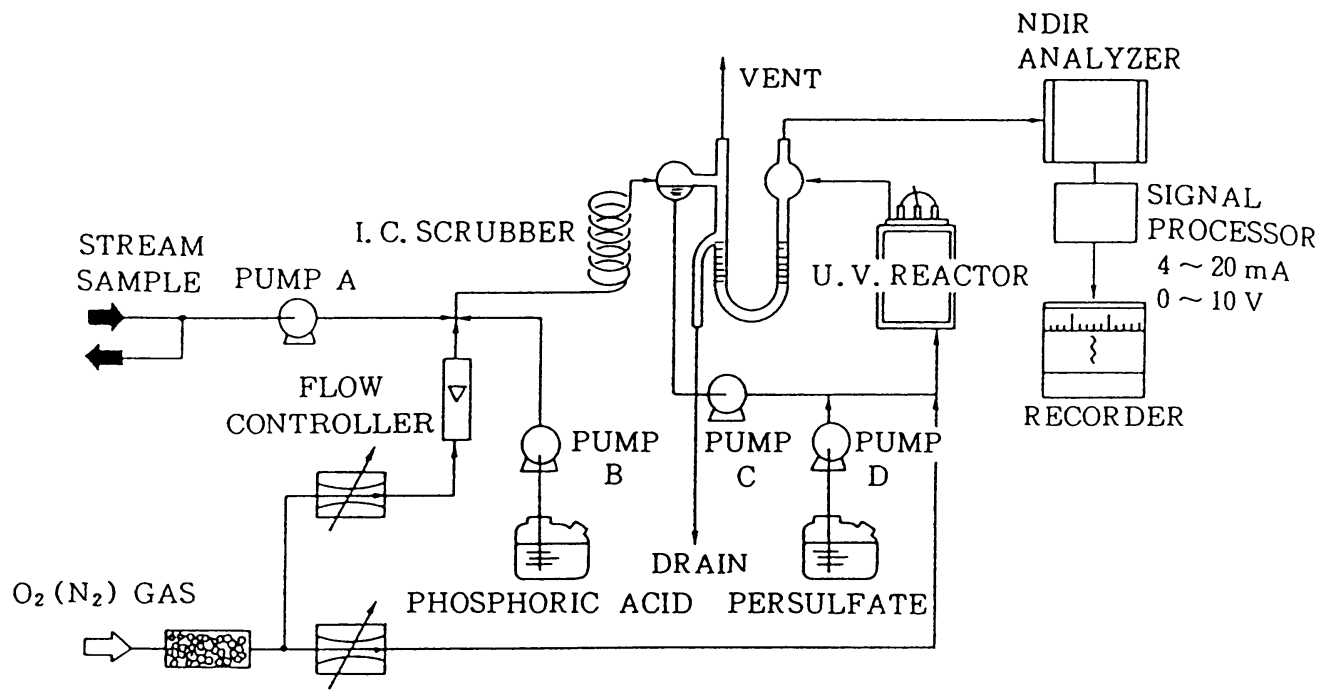

Figure 7 System-flow of TOC analyzer combined with UV decomposition instrument and persulfatedecomposition apparatus

(図 7 紫外線照射分解法と過硫酸カリウム分解法を組み合わせたTOC 分析計のシステム汹)

(B)

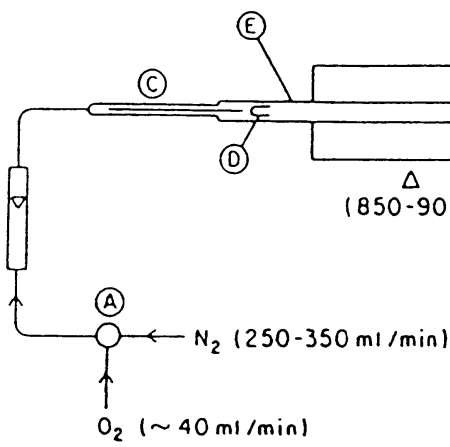

()

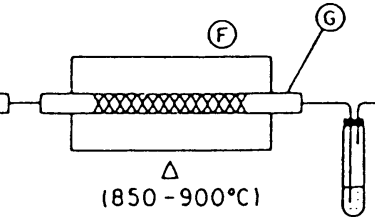

(A) (1)

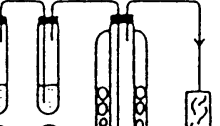
$0 . \mathrm{C} \frac{100}{(1)}$ $\circledast$

(A)

(M)

(B)

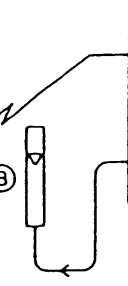

(1)

Figure 8 Dry oxidation system

(図 8 高温酸化分解法のシステム図)

A, Switching valve; B, system for pushing sample container into the oxidation zone $\left(850^{\circ} \mathrm{C}\right)$; C, flow meter; D, quartz container for salt sample; $\mathrm{E}$, quartz combustion tube; $\mathrm{F}$, muffle furnace $\left(850-900^{\circ} \mathrm{C}\right) ; \mathrm{G}$, combustion tube packed with platinized asbestos; $\mathrm{H}$, trap 1: acidified $\mathrm{FeCl}_{2}$ solution ( $25 \% \mathrm{w} / \mathrm{v}$ ); I, trap 2:acidified $\mathrm{Ag}_{2} \mathrm{SO}_{4}$ solution (saturated); J, cold trap $\left(0^{\circ} \mathrm{C}\right) ; \mathrm{K}$, anhydrone $\left[\mathrm{Mg}\left(\mathrm{ClO}_{4}\right)_{2}\right]$ column; L, non-dispersibe infrared analyzer; $\mathrm{M}$, integrator; $\mathrm{N}$, recorder.

凮することは, 試料に対する炭素の污染を避けるために は適切なプロセスではない。さらに $1000^{\circ} \mathrm{C}$ 付近の高温で の酸化は存機物の分解により二酸化炭素を生成するより も一酸化炭素の生成の割合を増加する问能性がある。た
とえ酸化銅が存在していたとしても，その酸化銅が溶融 した海塩によって被覆され, 酸化能力が低下する可能性 がある。この方法は, 湿式分解法に比べて酸化能力の点 では高いが, Gershey らの結果に見られるように, 湿式 
酸化法との差はそれほど大きくはない。高温燃焼酸化法 という基本原理は间じでありながら，なぜSkopintsev ${ }^{40)}$ と Gordon と Sutcliffe ${ }^{37}$ )らの得た高い做の結果とはかな り違うのか。この閣題について Mackinnonの結果以外 ほとんどの絬果は試料の桨素による污染のために高い值 になったとし，奌擝燃烧酸化法と湿式酸化法との間には 閌題にするほどの算はないと結㖮されることとなった。

\section{4 ) 高温接触酸化法}

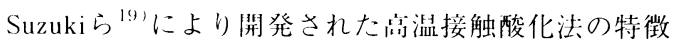
は，試料を万渦し酸性で炭酸塩を除上した後，海水試料 を電気灯で加熱された必伈管に淔接注入し，有機物を分 解することにある。そのため, 電気灯を横型から縦型に したこと,海塩の溶融を避けるため電気炉の温度を $680^{\circ} \mathrm{C}$ にしたこと，分解・酸化能力を高めるためにアルミナに $3 \%$ 白企を抽持した触媒を元填したことなどがあげら れる。Suzukiらによれば，万過をし崖酸塩を除去した後 50〜200 „Lの武料をマイクロシリンジ（最近著者らに より自動注人装置が開発された）で $3 \%$ 白金指持触媒を 允填した $680^{\circ} \mathrm{C}$ に加熱された必志管に通接注入し有機物 を分解する。生成した二酸化炭素は赤外線ガス分析計で 測定する。网 9 にSuzukiらにより開発された分析シス テムを示す。この方法を用いて海水中の溶存有機炭素の 濃度を測定したところ, 海水表面で100〜 $220 \mu \mathrm{mol} / \mathrm{L}$
となり，湿式法により得られた同じ海域の試料の測定結 果40〜80 $\mu \mathrm{mol} / \mathrm{L}$ に比べ高い值を得た。この濃度は Skopintsev や Gordon と Sutcliffe の結果とほぼ同じ程度 である。この結果は，海洋に扔ける炭素循環における有 機炭素の譻蔵量が海洋表層で従来の推定值の抢よそ2 倍 であることを示したこと，さらにこの方法と湿式法との 溶存有機炭素濃度の差は表曾で大きく，中深層でその差 が小さいことから，生物生産により生産されるフレッ シュな存機物ほど化学的酸化あるいは紫外線照射分解法 では分解しにくいという新たな問題を提示した。また， 従来海洋学に扔いて定量的な説明が十分できなかった酸 素消費量の問題や栄養塩の分解と地球規模の分布につい て跘明叮能な新たな力问を与えた。この方法による結果 は海洋化学・海洋生物学へ大きなインパクトを与えた。 日本に㧍いて開発された海水分析が国際的に大きな影響 を与えたつつである。そのため,この力法についての信 頼度に関する近試, 検討, 相互検定等が国際的に行われ た（1992年シアトルに扔いて天然水中の DOC / DON の 測定と題する国際会議が開かれた)。

この力法の問題点も高温燃焼酸化法と同じく電気炉付 近に用いら机ているコネクター（材料は金属合金）ある いはパッキング (フッ素ゴム) からの炭素成分の溶出が どれくらい活染として影響するかということ, 高温の電

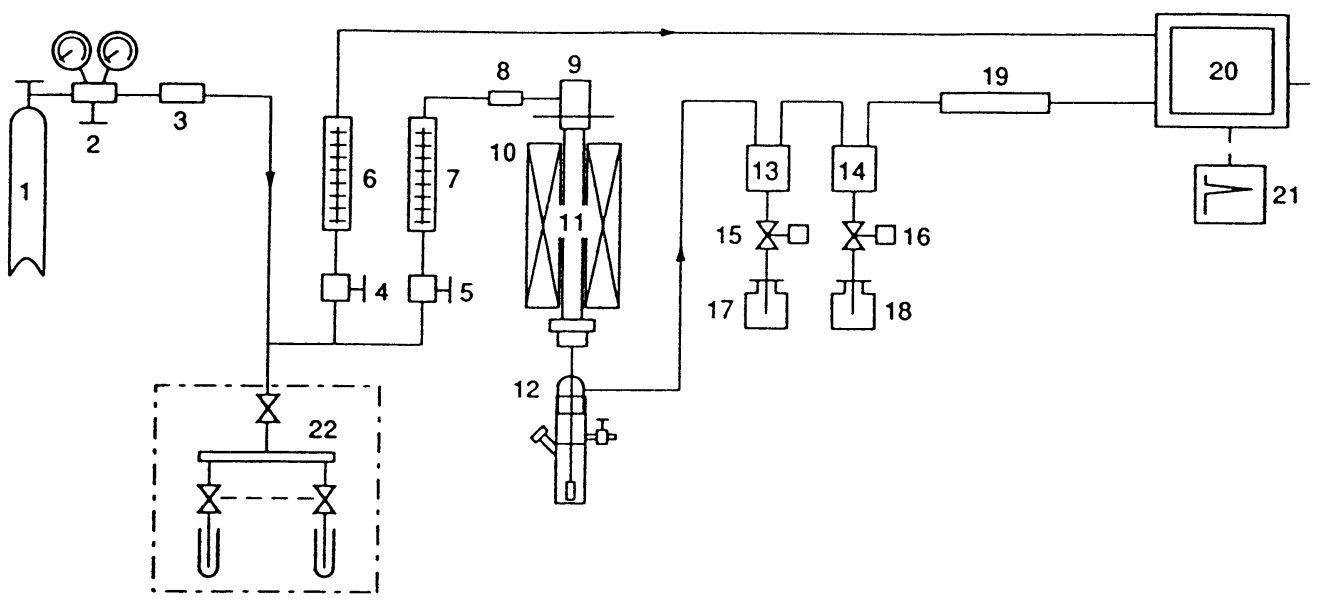

Figure 9 A diagram of the HTCO measuring system.

(図 9 高温接触酸化法のシステム図)

1, High-purity air or high-purity oxygen cylinder; 2, two-step, precision-type pressure regulator; 3 , ascarite column to trap $\mathrm{CO}_{2} ; 4$, flow controller (reference side of infrared gas analyser); 5, flow controller (sample side of infra-red gas analyzer); 6 and 7, flow meter $(200 \mathrm{~mL} / \mathrm{min})$; 8 , back-flush stop valve; $\mathrm{Q}$, injection port; 10 , electric furnace; 11 , combustion tube; 12, water trap; 13 and 14, electric condenser; 15 and 16. valve; 17 and 18, drain pot; 19 , magnesium perchlorate column; 20 , infrared gas analyzer; 21 , chromatocorder; 22 , purging system of inorganic carbon. 
Table 3 Levels of DOC in Seawater Determined Using Catalysts with Different Levels of Platinum

（表 3 高温接触酸化法における異なる白金含有量 の触媒を用いる海水と蒸留水中の DOC 濃 度の測定結果の比較)

\begin{tabular}{cccccc}
\hline & \multicolumn{5}{c}{ Platinum content of impregnated alumina (\%) } \\
\cline { 2 - 6 } $\begin{array}{c}\text { Depth } \\
\text { (m) }\end{array}$ & 0 & 0.5 & 1.5 & 3 & 5 \\
\hline 0 & 79.6 & 124 & 200 & 208 & 205 \\
20 & 90.4 & 106 & 202 & 188 & 196 \\
50 & 70.4 & 137 & 192 & 212 & 204 \\
100 & 84.6 & 122 & 204 & 190 & 203 \\
200 & 70.4 & 106 & 148 & 163 & 159 \\
400 & 60.8 & 67.4 & 142 & 140 & 152 \\
700 & 70.2 & 82.6 & 110 & 119 & 122 \\
900 & 72.4 & 90.4 & 92.4 & 102 & 109 \\
1000 & 65.6 & 64.6 & 96.0 & 96.2 & 106 \\
1500 & 64.4 & 70.4 & 88.8 & 92.4 & 108 \\
2000 & 69.4 & 70.8 & 98.3 & 92.8 & 104 \\
3000 & 65.6 & 63.2 & 94.8 & 96.5 & 112 \\
3508 & 66.7 & 64.6 & 101 & 103 & 108
\end{tabular}

Blank value

$33 \pm 4.4 \quad 24 \pm 1.2 \quad 27 \pm 1.8 \quad 19 \pm 0.8 \quad 22 \pm 1.0$

Seawater samples taken at $24^{\circ} 02^{\prime} \mathrm{S}, 157^{\circ} 08^{\prime} \mathrm{E}$ (February 1988; Hakuho-maru cruise $\mathrm{KH}-88-01$ of the Ocean Research Institute, University of Tokyo). (Suzuki et al., 1992)

気炉の中でどのように水蒸気が挙動しているのか, 用い た白金触媒は有機物の酸化分解においてべストかどうか 等である。表 3 に白金含有量の異なる触媒を用いた海水 中の DOC 濃度の測定結果の比較を示した。この結果か ら, 白金の含有量により有機物に対する酸化効率に差の あることが分る。同じ表にそれぞれの異なる触媒による ブランク值を示した。ブランク値の差は $10 \mu \mathrm{mol} / \mathrm{L}$ 程 度であり，表の海水中の DOCの濃度差に比べて小さい ことからこの差は異なる触媒による酸化効率の差といえ る可能性がある。しかしながら，安定な值を得るために は次のセクションで議論するような本質的な問題を解決 する必要がある。

\section{2 試料の保存とろ過}

海水中の溶存有機炭素の測定に限らず，環境水の分析 においては試料の採取・保存の問題，すなわちどのよう な採水器を使用するのか, 採取した試料をどのような行 器にどのように保存するのか, さらに試料はどのくらい の期閒保伱できるのかという問題をクリアーにしておか なければならない。この問題は測走法と同じく非常に重
要な問題であり，時には本質の理解を䛊らせることにな りかねない。ところが，この問題を定量的かつ系統的に 解決することは, 分析の問題を解決するより難しい要素 がある。それは海水試料中の物質の挙動, つまりさまさ まな有機化合物がどのような形で存在し，お互いの有機 化合物の間ではどのような相互作用があるのか，またコ ロイドで存在するのか, それは変化するのか等について ほとんど我々は知らないからである。換言すれば，海水 すなわちイオン強度の高い溶液中での有機化合物のコロ イド溶液化学を理解することである。しかしながら, 現 在の段階ではこれを定量的, 物理化学的に理解すること は困難である。そこで、採取する場所あるいは季節によ り, 生産される有機物は量的にも質的にもかなり違うこ とが予測されるので，いくつかの“ミニマムべター”を チェックしておく必要がある。試料の採取, 保存におい て重要なことは, 容器の材料の選定である。欲器の材料 として考慮しなければならない条件は，炭素成分を含ま ないかあるいは全く溶出しないかのどちらかである。こ の点では現在までの著者の経験ではガラス，しかもアシ ル化処理をしたものがベストである。その他, ポリカー ボネートあるいはポリスルホンの商器もほとんど問題が ない。もし海水試料を長時間保存しなければならない時 は褐色のガラスアンプルが良い。

次に試料のろ過は, 採取と闹時に完伞に外気から遮断 されたクローズのろ過システムを用いてできるだけ早く 行うべきであり，絶対に吸引ポンプを用いてろ過しては ならない。吸引ポンプを用いた場令，行器内が減けにとな り，混入した空気中の炭素成分で試料が必ず活染される からである。例えば，新鮮な蒸留水を無器の蓋をあけた まま放置しておくと，数分後には蒸留水中の荻素濃度は 非常に高くなる。一方, 万過に用いるフィルターは, 二ュ ウクレアポアフィルターが最も炭素の活染が少ない。ま たガラス繊維ろ紙，GFFあるいはGFCもあらかじめ $500^{\circ} \mathrm{C} て ゙$ 空焼したものを用いれば問題はない。ろ過した 試料水は褐色のガラスアンプルに移し, さらにバクテリ ア等の活動を抑えるために等素ガスで海水中の酸素を溯 換する。その後アンプルを封人する。もし，現場でろ過 ができない時でも，携带用の窣素ボンベを持参し，酸素 を置換するのが望ましい。

保存方法としては冷凍保你と冷蔵保仿があるが, 冷凍 保存はかなり試料の你在状態を变化させるため澼けたほ

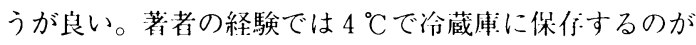
現在のところべストである。保你中の経時変化について

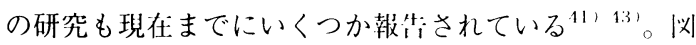
10にRomankevichにより検殒された経時変化の例を亦 した。一般的な傾问として，もし試料をほとんど処理せ ずに保存した場合，数日以内にDOC濃度は20～ $50 \%$ 近 く減少することが媳められる。この減少が海水試料中の 


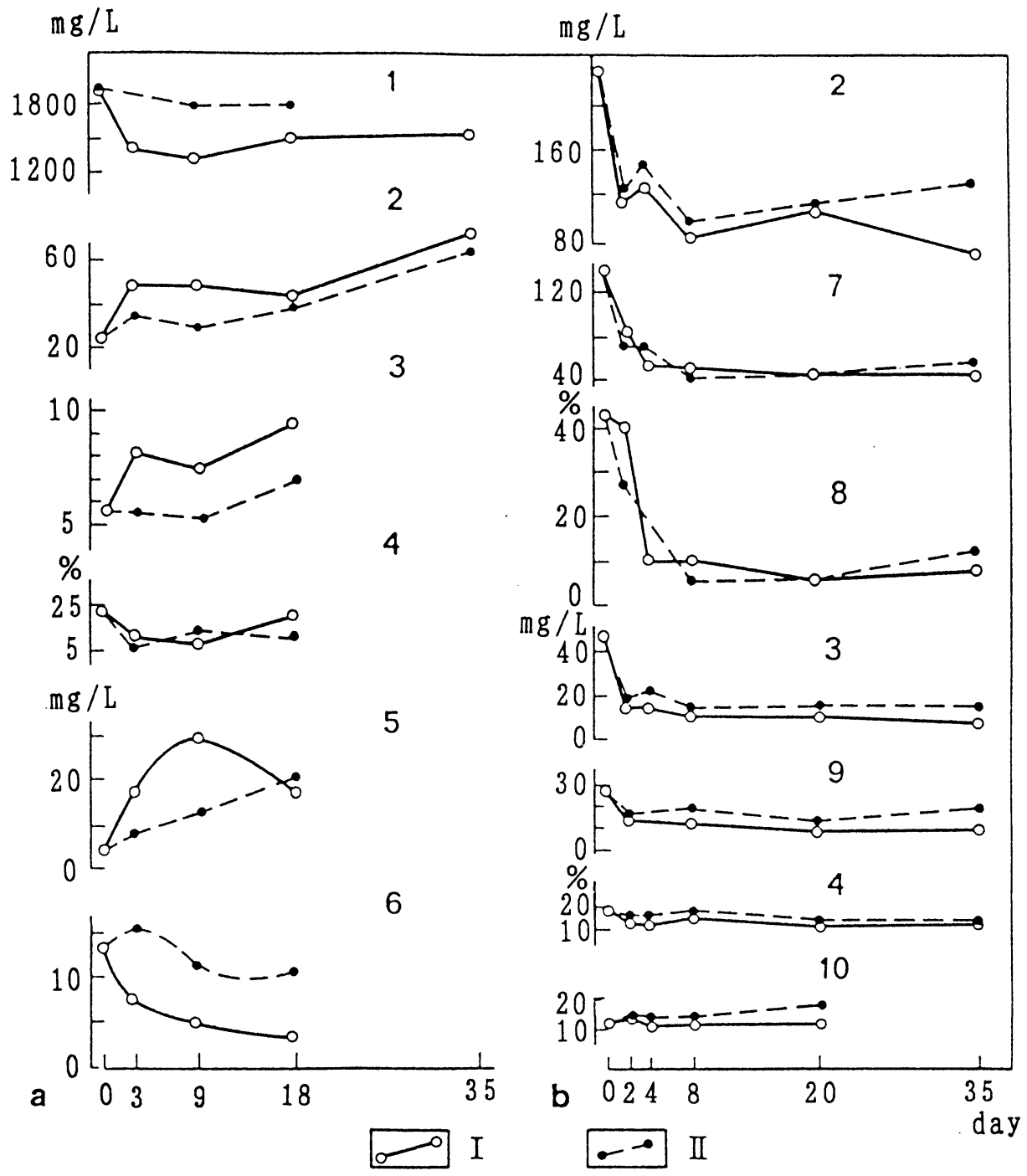

Figure 10 The kinetic of decay and neoforming of particulate OM from the dissolved one.

(汹10 海水中の溶存有機炭素および有機化令物の海水試料保存時における経時変化)

a, Western Equatorial-Tropical Pacific; b, shelf off Peru.

I. Experiment carried out at $30^{\circ} \mathrm{C}$; II, Experiment carried out at $6{ }^{\circ} \mathrm{C}$

1, DOC; 2, POC; 3, $\mathrm{C}_{\mathrm{CHC}}$ in suspended matter; 4, part of $\mathrm{C}_{\mathrm{CHC}}$ in POC; 5 , bacterial biomass;

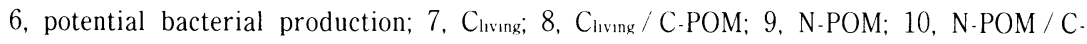
POM.

バクテリアによる分解なのが11，あるいは保份行监の 器譬への吸住なのか (Borsheim からの私信，1993年）

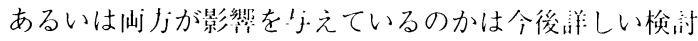
が必装である。武料の保仿に関しては解明すべき未知の 問題が多く，特にこのような保们念験はたとえ间一の試

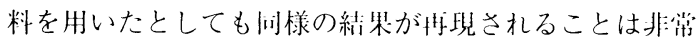
にまれである。良って，海水中の溶你存機岑素の測定を
行う場命，試料採取後川能な限り速やかに現場において 測定することが望ましい。

\section{6. 海水中の溶存有機炭素測定における問 題点}

高温接触酸化法による測定值が化学的酸化法あるいは 紫外線照射分解法に比べて 50 ～150\%の高い值を示した 
ことは, 前述したように“海洋化学・海洋生物学”の分 野に扔いては非常に重要な意味を持っている。それだけ に, 国際的にも高温接触酸化法についての検討, チェッ クはここ数年厳しく行われている。はじめの内は 2,3 の研究室間に扔ける試料の相互交換と相互検定が行われ た。この結果の一部をまとめたのが表 4 である。ここで HTCO というのが高温接触酸化法のことである。この表 でみられるように著者らの值は, 他の研究室で独自に高 温接触酸化法で分析された結果とよく一致しているし, またその值は過硫酸カリウム法により測定された值に比 べて高い。そこで, 1992年米国の全米科学財団の支援で 国際的なワークショップがシアトルで開かれた（筆者は この組織委員会のメンバーの一人)。ワークショップが 開かれる前に組織委員会は世界の DOC 研究者のほとん どにハワイ沖で採取した海水試料 (表層, 中層, 深層水) を配布し，それぞれの研究室で最も得意とする方法で分
析し, 結果を報告するよう要請した。表 5 に示されてい る研究者がそれぞれの方法で参加し，その結果が図11に まとめられている。驚くべきことに同一の試料を分析し たにもかかわらず，測定值には35～330 $\mu \mathrm{mol} / \mathrm{L}$ と 10倍 の開きがあった ${ }^{45)}$ 。会議の期間中この問題を含めて溶 存有機炭素測定法の問題点が議論された。この会議の記 録は1993年 3 月に“Marine Chemistry”誌に掍載された。 最も重要な議論は“ブランク值”をどのように評価する かであった。有機炭素の分析に打いて常につきまとう問 題は分解過程で炭素の污染があるかないかである。これ を“システムブランク”という。これ以外に標準の有機 化合物の調製に用いられる蒸留水中の有機物の炭素があ り，これを“水ブランク”という。現在のところ有機炭 素を $100 \%$ 含まない蒸留水を得ることは不叮能である。 したがって，どのような酸化法を用いても“測定された ブランク值”は“システムと水”の両方を含んでいる。

Table 4 Summary of DOC Levels in Seawater Determined Recently by High-Temperatured Catalytic Oxidation and Persulfate Oxidation

（表 4 最近測定された異なる高温接触酸化法と湿式酸化法による海水中の DOC 濃度のまとめ)

\begin{tabular}{|c|c|c|c|}
\hline Location of samples & Method or instrument & Analyst or group & $\begin{array}{c}\text { Range of concentraton }(/ \mu \mathrm{MolC} / \\
\mathrm{L})\end{array}$ \\
\hline \multirow[t]{3}{*}{ Delaware Estuary } & HTCO-MRI-Sumika & Suzuki & $164-304$ \\
\hline & HTCO-Shimadzu TOC 500 & Mundy & \\
\hline & Persulfate & Sharp & \\
\hline \multirow[t]{3}{*}{ Central Pacific } & HTCO-MRI-Sumika & Suzuki & $108-218$ \\
\hline & HTCO-MLML & Fitzwater & $89-231$ \\
\hline & UV oxidation & Williams & $38-90$ \\
\hline \multirow[t]{3}{*}{ North Atlantic } & HTCO-MRI-Sumika & Suzuki & $114-250$ \\
\hline & HTCO-Ionics-WHOI & Peltzer & $114-239$ \\
\hline & HTCO-PML-Shimadzu 500 & Miller & \\
\hline \multirow[t]{2}{*}{ N. Central Pacific } & HTCO-MRI-Sumika & Suzuki & $90-218$ \\
\hline & HTCO-SIO & Williams & $81-130$ \\
\hline \multirow[t]{2}{*}{ Sargasso Sea } & HTCO-MRI-Sumiks & Suzuki & $96-138$ \\
\hline & HTCO-SIO & Bauer & $82-119$ \\
\hline \multirow[t]{3}{*}{ Station P } & HTCO.WHOI & Peltzer & $78-90$ \\
\hline & HTCO-WHOI-lonics & Peltzer & $81-102$ \\
\hline & HTCO-Shimadzu 500 & C. S. Wong & $52-68$ \\
\hline \multirow[t]{3}{*}{ Gulf of Lions } & HTCO-LSGM (France) & Cauwet & $62-156$ \\
\hline & HTCO-Shimadzu 500 & Cauwet & $49-90$ \\
\hline & Persulfate & Cauwet & $71-123$ \\
\hline \multirow[t]{2}{*}{ California Bight } & HTCO-UCSC-SIO & Hansell & $80-140$ \\
\hline & Persulfate & Hansell & $40-80$ \\
\hline \multirow[t]{2}{*}{ North Atlantic } & HTCO-NIOZ-Shimadzu & De Baar & $110-150$ \\
\hline & HTCO-NIOZ-Ionics & De Barr & $50-160$ \\
\hline Indian Ocean & HTCO-Carlo Erba & Kumar et al. & $50-300$ \\
\hline
\end{tabular}


Table 5 Summary of Cross-Check for Levels of DOC in the Common Water Sample Distributed by DOC / DON Workshop in Seattle, U.S.

(表 5 シアトルの DOC / DONワークショップにおいて配布された試料水中の DOC 濃度を測定した 各研究者とその測定方法のまとめ)

\begin{tabular}{|c|c|c|c|c|c|c|c|c|}
\hline $\begin{array}{l}\text { Workshop } \\
\text { Participant }\end{array}$ & $\begin{array}{l}\text { Analyst } \\
\text { Name }\end{array}$ & $\begin{array}{l}\text { Analyzer } \\
\text { Type }\end{array}$ & Analyzer Model & $\begin{array}{c}\text { Reaction } \\
\text { Temperature, }{ }^{\circ} \mathrm{C}\end{array}$ & $\begin{array}{l}\text { Catalyst } \\
\text { Type }\end{array}$ & $\begin{array}{l}\text { Wt } \% \\
\mathrm{Pt}\end{array}$ & $\begin{array}{l}\text { Oxidant } \\
\text { Species }\end{array}$ & $\begin{array}{c}\text { Reacted } \\
\text { Volume, } / / \mathrm{L}\end{array}$ \\
\hline Alperin & Alperin & HTCO & Shimadzu TOC -5000 & 680 & Normal Pt & 0.5 & $\mathrm{O}_{2}$ & 100 \\
\hline Alperin & Alperin & HTCO & Sealed tube & 850 & $\mathrm{CuO} / \mathrm{Ag}$ & 0 & $\mathrm{O}_{2}$ & 3,000 \\
\hline Benner & Strom & $\mathrm{HTCO}$ & Shimadzu TOC -5000 & 680 & Normal Pt & 0.5 & $\mathrm{O}_{2}$ & 200 \\
\hline Burdige & Homstead & HTCO & Shimadzu TOC-5000 & 680 & Normal Pt & 0.5 & $\mathrm{O}_{2}$ & 100 \\
\hline Cauwet & Cauwet & HTCO & Shimadzu TOC -5000 & 680 & $\mathrm{Pt} / \mathrm{Al}_{2} \mathrm{O}_{3}$ & 3 & $0_{2}$ & 100 \\
\hline Doering & McKenna & WCO & OI $700-\mathrm{TOC}$ & 100 & None & 0 & $\mathrm{~K}_{2} \mathrm{~S}_{2} \mathrm{O}_{8}$ & 343 \\
\hline Ertel & Ertel & HTCO & Ionics 555 & 680 & $\mathrm{Pt}$ & 100 & $\mathrm{O}_{2}$ & 100 \\
\hline Fry & Fry & HTCO & Sealed tube & 590 & $\mathrm{PtCl}_{6}$ & $?$ & $\mathrm{CuO}$ & $2,000-18,000$ \\
\hline Hansell & Hansell & HTCO & HM Suzuki Clone & 710 & $\mathrm{Pt} / \mathrm{Al}_{2} \mathrm{O}_{3}$ & 3 & $\mathrm{O} 2$ & 100 \\
\hline Hegeman & Hegeman & WCO & OI $700-\mathrm{TOC}$ & 100 & None & 0 & $\mathrm{~K}_{2} \mathrm{~S}_{2} \mathrm{O}_{8}$ & 1,000 \\
\hline Hopkinson & Padien & HTCO & Ionics 1500 & 770 & $\mathrm{Pt}$ & 100 & $\mathrm{O}_{2}$ & 161 \\
\hline Ionics & Ghotbi & HTCO & Ionics 555 & 795 & $\mathrm{Pt}$ & 100 & $\mathrm{O}_{2}$ & 100 \\
\hline Ittekkot & Raabe & HTCO & Carlo Erba TOM-480 & 1,020 & $\mathrm{NiO}$ & 0 & $?$ & $9,000 /$ cycle \\
\hline Kahler & Kahler & HTCO & Dimatek TOC-100 & 900 & Pt wool & 100 & $\mathrm{O}_{2}$ & 100 \\
\hline Karl & Tien & HTCO & lonics 555 & 780 & $\mathrm{Pt}$ & 100 & $\mathrm{O}_{2}$ & 100 \\
\hline Mantoura & S.Jones & WCO & HM Automatic UV/P & 100 & None & 0 & $\mathrm{UV} / \mathrm{K}_{2} \mathrm{~S}_{2} \mathrm{O}_{8}$ & 10,000 \\
\hline Martin & Fitzwater & HTCO & Dohrmann DC-190 & 680 & $\mathrm{Pt}$ & $?$ & $\mathrm{O}_{2}$ & 50 \\
\hline Corkle & Martin & HTCO & HM Suzuki Clone & 800 & Pt-gauze & 100 & $\mathrm{O}_{2}$ & 300 \\
\hline Miller & Mantoura & WCO & HM Automatic UV-P & 100 & None & 0 & $\mathrm{UV} / \mathrm{K}_{2} \mathrm{~S}_{2} \mathrm{O}_{8}$ & 4,000 \\
\hline Miller & Mantoura & HTCO & Shimadzu TOC -500 & 680 & Normal Pt & 0.5 & $\mathrm{O}_{2}$ & 80 \\
\hline Norrman & Norrman & HTCO & Shimadzu TOC -5000 & 680 & Normal Pt & 0.5 & $\mathrm{O}_{2}$ & 100 \\
\hline Peltzer & Peltzer & HTCO & HM Suzuki Clone & 800 & $\mathrm{Pt} / \mathrm{Al}_{2} \mathrm{O}_{3}$ & 5 & $\mathrm{O} 2$ & 100 \\
\hline Perdue & Lu Sun & HTCO & Coulometrics 5020-TC & 900 & $\mathrm{BaCrO}_{3}$ & 0 & $\mathrm{O}_{2}$ & 200 \\
\hline Rosemont & Ton & HTCO & Dohrmann DC-190 & 680 & $\mathrm{Pt} / \mathrm{Al}_{2} \mathrm{O}_{3}$ & 1 & $\mathrm{O}_{2}$ & 100 \\
\hline Spitzy & Fengler & HTCO & Ionics 555 & 800 & $\mathrm{Pt}$ & 100 & $\mathrm{O}_{2}$ & 100 \\
\hline Suzuki & Suzuki & HTCO & Sumigraph TOC -90 & 680 & $\mathrm{Pt} / \mathrm{Al}_{2} \mathrm{O}_{3}$ & 3 & $\mathrm{O}_{2}$ & 50 \\
\hline Tanoue & Tanoue & HTCO & Sumigraph TOC -90 & 680 & $\mathrm{Pt} / \mathrm{Al}_{2} \mathrm{O}_{3}$ & 3 & $\mathrm{O}_{2}$ & 100 \\
\hline Tugrul & Morkoc & HTCO & Shimadzu TOC- 500 & 680 & HiSens Pt & $?$ & $\mathrm{O}_{2}$ & 200 \\
\hline Tugrul & Hatipoglu & WCO & Technicon AII & 100 & None & 0 & $\mathrm{UV} / \mathrm{K}_{2} \mathrm{~S}_{2} \mathrm{O}_{8}$ & 1.500 \\
\hline Walsh & Walsh & WCO & OI 700-TOC & 100 & None & 0 & $\mathrm{~K}_{2} \mathrm{~S}_{2} \mathrm{O}_{8}$ & 2,600 \\
\hline Wangersky & Chen & HTCO & HM Suzuki Clone & 710 & $\mathrm{Pt} /$ Kaowool & 5 & $\mathrm{O}_{2}$ & 100 \\
\hline Wangersky & Chen & WCO & HM Automatic UV/P & 100 & None & 0 & UV & 4,000 \\
\hline PM Williams & Wolgast & HTCO & HM Suzuki Clone & 680 & $\mathrm{Pt} / \mathrm{Al}_{2} \mathrm{O}_{3}$ & 3 & $\mathrm{O} 2$ & 100 \\
\hline PM Williams & Wolgast & HTCO & HM Suzuki Clone & 680 & $\mathrm{AlSiO}_{4}$ & 0 & $\mathrm{O}_{2}$ & 100 \\
\hline
\end{tabular}

$\mathrm{HTCO}=$ high temperature catalytic oxidation, $\mathrm{WCO}=$ wet chemical oxidation, $\mathrm{HM}=$ home made. $\mathrm{UV} / \mathrm{P}=\mathrm{UV} /$ persulfate.

これを分離することは可能なのか。特に高温接触酸化法 あるいは高温燃焼酸化法の場合，たしかに湿式酸化法に 比べてブランク值は高い19)。このブランク值の差をそ のままシステムブランクの差と考えて良いのだろうか。 システムブランクを評価する方法として考えられている のは，1）検量線の濃度ゼロの時の切片がそれを示すと 考える方法，2）有機炭素濃度ゼ口の水を調製し，それ を用いて評価する方法がある。Suzukiら ${ }^{19)}$ は一度高温 接触酸化法で分解した蒸留水を外気と触れないように注 意深く捕集し, 再び高温接触酸化法により測定し，その
值をシステムブランクとした。表 6 にその結果を示して ある。これによるとシステムからの炭素の污染は非常に 小さいことがわかる。ただし，この結果を再現すること もまた容易でないため, 現在でもこの問題に結着がつい ていない。もし, システムブランクの值が水ブランク值 に比べて小さいとすると, 表 6 の結果の HTCO 法と湿 式法との差は酸化効率の差ということになる。蒸留水中 の有機物でさえ湿式法では分解し得ないものがあること になる。“システムブランク”の評価と“酸化効率”の 評価,このどちらも現在の段階では決定打が見出されて 


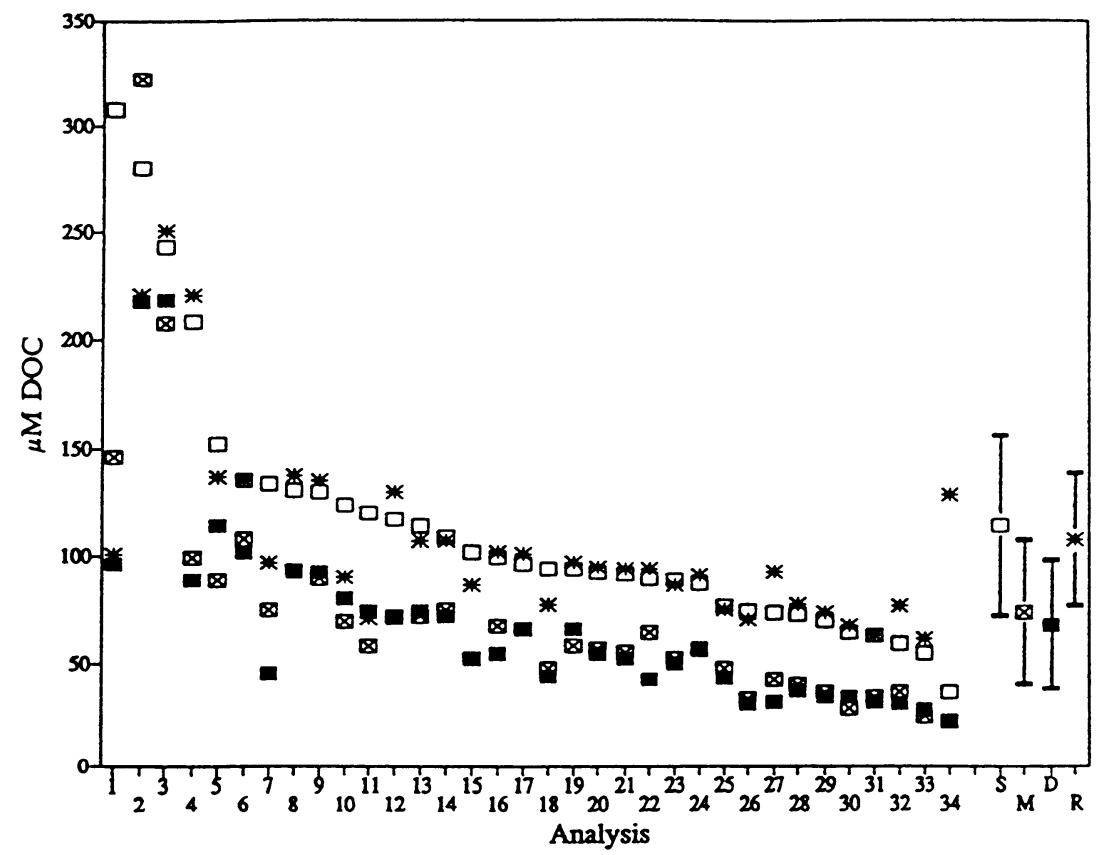

Figure 11 Trends in measured DOC among 34 analyses of four reference natural water samples.

（図114つの異なる海水および淡水中のDOC 濃度を34の異なる研究室において測定した結果）

Analyses are listed in order of decreasing concentration for the surface seawater sample. The symbols to the right represent the $( \pm 1$ mean deviation interval) for all analyses of each sample. The sample mean deviation is defined as $\left(\Sigma \backslash X_{1}-X_{m} \backslash\right) / n$, where $X_{m}=$ the mean and $\mathrm{n}=$ the number of samples analyzed. Symbol codes: open boxes $=$ surface $(10.5 \mathrm{~m})$ seawater, crossed boxes $=$ mid-depth $(766 \mathrm{~m})$ seawater, filled boxes $=$ deep $(4,001 \mathrm{~m})$ seawater, asterisks $=$ river water.

Table 6 The Values of Blank Controls (for Water and for the System) from Methods Employing HTCO, Photo-Oxidation and Persulfate, and the System Blank Determined with the Water Collected after HTCO

(表 6 同一の蒸留水を用いた異なる酸化分解法による蒸留水中の DOC 濃度の比較と高温接触酸化 法により調製された蒸留水を用いる高温接触酸化法のシステムブランク值)

\begin{tabular}{cccc}
\hline & $\begin{array}{c}\text { HTCO } \\
(\mu \mathrm{MC})\end{array}$ & $\begin{array}{c}\text { Photo-oxidation } \\
(\mu \mathrm{MC})\end{array}$ & $\begin{array}{c}\text { Persulfate oxidation } \\
(, \mu \mathrm{MC})\end{array}$ \\
\hline Water blank $^{*}+$ system blank \\
Average \\
Range
\end{tabular}

\footnotetext{
* Organic matter originally in deionized water.

${ }^{+}$Contamination from catalyst, $\mathrm{CuO}$, sulfix, connector, tube, carrier gas and handling.
} 
いない。今後もこの問題をクリアーにするために多くの

時間と努力が費やされることであろう。

\section{7. まとめ}

海水中の溶存有機炭素の測定法の現状と地球環境問題 における意義について簡単に述べてきた。この総説は単 に測定法の技術的な問題について述べたものではない。 環境科学あるいは環境化学に打ける測定法あるいは技術 の開発は“自然を認識する”という前提があってはじめ て意味のある正確な方法が確立できるのである。伝統的 な分析化学の思考方法の“マニュアル”(例えば標準品 の回収率が $100 \%$ であるから環境における対象の化学物 質の測定值も間違いないとすること）か環境を理解する ための手段としての分析方法であるはずなのに，時とし て“事実”とはかけ離れた結論を出してしまうことがあ る。

環境試料中の対象物質は同一元素でもさまざまな化学 形で存在している。しかも，その分布のしかたは均一で あるもの，不均一であるものとさまざまである。そして， 最大の問題は, 海水中の溶存有機炭素の例で述べたよう に，測定対象物質の実態がほとんど解明されていないこ とである。それだけに，“環境化学”においては，測足 結果に対して，何をどのくらい確実に測定しているのか を常に注意墚く吟味する必要がある。地球環境問題は, 実は“真”の自然環境の姿を知れということを我々に問 題として投げかけているのである。それはまた，環境に 扔ける測定法あるいは技術が“Science”と一体化する 時代をも求めている。

\section{文 献}

1) Rotty. R. M.. Marland, G. and Treat, N.: Pattern of fossil fuel CO. emmisions. (DOE/OR/21400-2). USADOE (1984).

2) Takahashi, T.: Carbon dioxide in the atmosphere and in Atlantic Ocean water. J. Geophys. Res.. 66. 479-494 (1961).

3) Miyake, Y. and Suginura, Y.; CO., in surface water and the atmosphere in the Pacific-Indian and the Antarctic Ocean areas. Rec. Oceanogr. Works Jpm., 10. 23-28 (1968).

4) Keil, R. (j. and Kirchman, D. L.: Dissolved combined amino acid in marine waters as deternined by a vapor-phase hydrolysis method. Mar. Chem., 40. 235-243 (1992).

5) Williams, P. M.; The determination of dissolved organic carbon in sea water: A comparison of two methods. Limnol. ()ceanogr., 14, 297-298 (1969).

6) Suzuki, Y.: Dynamic cycle of dissolved organic car bon and marine productivity. In "Global Carbon $\mathrm{Cy}$ cles of NATO-ASI". eds. by M. Heimann (in press).

7) Martin, J. H., Knauer, G., Karl, D. M. and Broenkow: VERTEX: Carbon cycling in the northeast Pacific. Deep-Sea Res., 34, 1293-1309 (1987).

8) Sugimura, Y. and Suzuki, Y.; High temperature cat alytic oxidation method for the determination of nonvolatile dissolved organic carbon in seawater by direct injection of a liquid sample. Mar. Chem.. 24. 105-131 (1988).

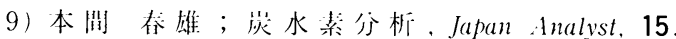
711-726 (1966).

10）蒲牛，俊敬；荻絭，ぶんせき，No.8，592-593 (1993).

11) Duursma, E. K.: Dissolved organic carbon, nitrogen. and phosphorus in the sea. Veth. J. Sea Res., 1. 1-148 (1961)

12) Holm-Hansen, O.. Strikland. J. D. H. and Williams, P. M.; A detailed analysis of biologically important sub. stances in a profile of southern California. Limnol. Oceanogr., 11, 548-561 (1966).

13) Menzel, D. W. and Vaccaro, V. F.; The measurement of dissolved organic and particulate carbon in sea water. Limnol. Oceanogr., 9, 138-142 (1964).

14) Duursma, E. K.; The dissolved organic constituents of seawater. In "Chemical Oceanography, Vol.1", eds. by J. P. Riley and (G. Skirrow. Academic Press, New York, pp.433-475 (1965).

15) Sharp. J. H.; Total organic carbon in seawater comparison of measurement using persulfate oxidation and high temperature combustion. Mar. Chem.. 1. 211-229 (1973).

16) Gershey, R. M., Mackinnon, M. D. and Williams, P. J. L.: Comparison of three oxidation methods used for the analysis of the dissolved organic carbon in sea. water. Mar. Chem.. 7, 289-306 (1979).

17) Brewer. P. G.. Bruland, K. W., Eppley, R. W. and MaCarthy, J. J.; The global ocean flux study (GOFS): Status of the U.S. (iofS Program. EOS. 67, 827-832 (1986).

18) Toggweiler, J. R.. Sarmiento, J. L. and Najja, R.: Mod. els of chenical creling in the oceans: A progress re. port. Ocean Tracers Laboratory Technical Report 4. AOSC. Princeton Universit!. pp.61 (1987).

19) Suzuki, Y.. Tanoue. E. and Ito, H.; A high tempera ture catalytic oxidation for the determination of dis solved organic carbon in seawater: Analysis and im. provement. Deep Sea Res., 39. 185-198 (1992). 
20) Maciolek, J. A.; Limnological organic analyses by quantitative dichromate oxidation. I'. S. Fish Wildl. Sert. Re's. Rept., 60, 1-60 (1962).

21) Krey, J. and Szekielda, K. H.; Bestimung des organisch gebundenen Kohlenstoffs in meerwasser mit neuen Gerat zur Analyses sehr kleiner Mengen CO. Zeitschr. Anal. Chem., 207. 338-346 (1965).

$22)$ Oppenheimer. C. H., Corcoran, E. F. and Van Arman, J.: Method for the determination of organic carbon in sea water. Limnol. Océanogr., 8, 487-488 (1963).

23) Menzel. D. W. and Vaccaro, V. F.; The measurement of dissolved organic and particulate carbon in seawater. Limnol. Occanogr., 9. 138-142 (1964).

$24)$ Bikbulatov, E. S.: Simple process for the oxidation of organic material of natural waters for determining carbon. (iidrokhim. Mater., 60, 174-178 (1974).

$25)$ Boehm. H.; Method for the quick determination of organic carbon using a wet oxidation method. Acta Hydrochim. Hydrobiol., 3. 327-332 (1975).

26) Goulden. P. H. and Anthony, D. H. J.; Kinetics of uncatalyzed peroxy disulfate oxidation of organic material in fresh water. Anal. Chem., 50, 953-958 (1978).

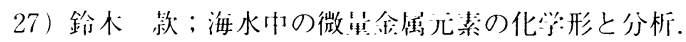
海洋科兴， 14，292-297 (1982).

28) Nakayama, E.. Suzuki, Y., Fujiwara, K. and Kitano, $Y$ : Chemical analyses of seawater for trace elements recent progress in Japan on clean sampling and chemical speciation of trace elements. Anal. Sci., 5 . 129-139 (1989).

29) Beattie, J., Bricker, C. and Garvin, D.: Photolytic determination of trace amounts of organic material in water. Anal. Chem., 33. 1890-1892 (1961).

30) Armstrong, F. A. J., Williams, P. M. and Strickland, J. D. H.: Photooxidation of organic matter in sea water by ultraviolet radiation, analytical and other applications. Nature, 211, 481-483 (1966).

31) Ehrhardt, M.; A new method for the automatic measurement of dissolved organic carbon in sea water. Decp-Sea Res., 16, 393-397 (1969).

32 ) Woelfel, P. and Sontheimer, H.: New procedure for the determination of organically bound carbon in water using photochemical oxidation. Vom. Wasser, 43, 315-325 (1974).

33) Propp. M. V. and Propp. L. N.: Determination of dis- solved organic matter in the sea water by photochemical combustion. Okenologiia, 17, 638-645 (1977).

34) Collins, K. J. and Williams. P. J. I.; An automated photochemical method for the determination of dissolved organic carbon in sea and estuarine waters. Mar. Chem., 5, 123-141 (1977).

35) Mueller, H. and Bandaranayake, W. M.; An automated method for the determination of dissolved organic carbon in sea water using continuous thin film UV oxidation. Mar. Chem., 12, 59-68 (1983).

36) Cauwet. G.: Automatic determination of dissolved organic carbon in seawater in the subppm range. Mar. Chem., 14, 297-306 (1984).

37 ) Gordon. D. C.. Jr. and Sutcliffe, W. H., Jr.: A new dry combustion method for the simultaneous determination of total organic carbon and nitrogen in sea water. Mar. Chem., 1. 231-244 (1973).

38) MacKinnon, M. D.: A dry oxidation method for the analysis of the TOC in sea water. Mar. Chem.. 8 . 143-162 (1979).

39) Fry, B. S. S.. Hullar. M. and Peterson, B. J.; Platinum-catalyzed combustion of DOC in sealed tubes for stable isotopic analysis. Mar. Chem., 41, 187-193 (1993).

40) Skopintsev., B. A.: Organic matter in sea water. Trudy Mar. Hydrophys. Inst., 19, 1-14 (1960).

41) Otson, R., Williams, D. T., Bothwell, P. D., McCullough, R. S. and Tate, R. A.; Effects of sampling. shipping and storage on total organic carbon levels in water samples. Bull. Environ. Contam. Toxicol., 23, 311-318 (1979).

42 ) Romankevich, E.; “Geochemistry of organic matter in the ocean", Springer-Verlag Berlin, pp.1-304 (1984).

43 ) Peltzer, E. T. and Brewer, P. G.; Some practical aspects of measuring DOC-sampling artifacts and analytical problems with marine samples. Mar. Chem., 41, 243-253 (1993).

44) Kirchman, D. L., Suzuki, Y.. Garside, C. and Ducklow, H. W.; High turnover rates of dissolved organic carbon during a spring phytoplankton bloom. Nature, 352, 612-614 (1991).

$45)$ Williams, P. M.: Measurement of dissolved organic carbon and nitrogen in natural waters. Oceanography. 5, 107-116 (1992). 